\title{
The Genetic Epidemiology of Joint Shape and the Development of Osteoarthritis
}

\author{
J. Mark Wilkinson ${ }^{1}$ (D) Eleftheria Zeggini ${ }^{2}$
}

Received: 13 January 2020 / Accepted: 29 April 2020 / Published online: 11 May 2020

(c) The Author(s) 2020

\begin{abstract}
Congruent, low-friction relative movement between the articulating elements of a synovial joint is an essential pre-requisite for sustained, efficient, function. Where disorders of joint formation or maintenance exist, mechanical overloading and osteoarthritis (OA) follow. The heritable component of OA accounts for 50\% of susceptible risk. Although almost 100 genetic risk loci for OA have now been identified, and the epidemiological relationship between joint development, joint shape and osteoarthritis is well established, we still have only a limited understanding of the contribution that genetic variation makes to joint shape and how this modulates OA risk. In this article, a brief overview of synovial joint development and its genetic regulation is followed by a review of current knowledge on the genetic epidemiology of established joint shape disorders and common shape variation. A summary of current genetic epidemiology of OA is also given, together with current evidence on the genetic overlap between shape variation and OA. Finally, the established genetic risk loci for both joint shape and osteoarthritis are discussed.
\end{abstract}

Keywords Genetics · Epidemiology $\cdot$ Joint development $\cdot$ Joint shape $\cdot$ Osteoarthritis

\section{Introduction}

Osteoarthritis (OA) is a disorder involving movable joints characterized by cell stress and extracellular matrix damage leading to cartilage degradation, bone remodelling, osteophyte formation, joint inflammation and loss of normal joint function that manifests clinically with pain, deformity, and disability https://www.oarsi.org/education/oarsi-resources/ oarsi-white-paper-oa-serious-disease. Approximately, 240 million people (3.3\% of the world's population) live with OA [1]. Between 1990 and 2013 osteoarthritis was responsible for a $75 \%$ increase in years living with disability to 13 million [2], behind only diabetes (135\%) and dementia (84\%) in increasing prevalence. This reduced physical activity results in an increased all-cause mortality for OA sufferers versus the general population (standardised mortality ratio 1.55 ,

J. Mark Wilkinson

j.m.wilkinson@sheffield.ac.uk

1 Department of Oncology and Metabolism, University of Sheffield, Sheffield, UK

2 Institute of Translational Genomics, Helmholtz Zentrum München - German Research Center for Environmental Health, Neuherberg, Germany
95\% confidence interval 1.41-1.70) [3], largely attributable to an excess cardiovascular risk. In 2003, OA accounted for $1.2 \%$ of United States domestic product ( $\$ 128$ billion, direct costs $\$ 80$ Billion and loss of earnings \$47Billion) [4]. By 2013, this figure had increased to \$304Billion [5].

The epidemiological risk factors for OA are well-established and include older age, female sex, obesity, joint injury, bone morphology and family history. The heritability of OA has been estimated in studies of monozygotic versus dizygotic twins to range between $40 \%$ (knee) and 60\% (hip) $[6,7]$, and follows a non-Mendelian pattern consistent with the common, complex nature of the disease. The interaction between environmental and heritable risk factors for OA also differs with age, between men and women, and with body mass index [8]. In recent years it has become more widely appreciated that underlying joint shape is a strong risk factor for OA. This realisation has led to an explosion in the use of surgical interventions designed to restore the joint to a more anatomically normal shape and improve mechanical symptoms [9-11]. Only time will establish whether such interventions alter the natural history of OA. In this article, we provide a brief overview of the morphology and development of synovial joints, review the genetic epidemiology 
of joint shape as it relates to OA genetic epidemiology, and consider to what extent this heritable component is shared.

\section{What is a Synovial Joint?}

Synovial joints, characterised by a fluid-filled synovial space between the bones, are the most flexible type of joint in the body, allowing movement between the bone ends in up to 6 degrees of freedom and across an arc of movement of up to 140 degrees. Synovial joints are the most common type of joint, and allow great facility in both the range and type of movement from repetitive, weight-bearing activity through to intricate, fine motor functions. Such freedom of movement and resilience requires exquisite design. All synovial joints comprise subchondral bone that is lined by hyaline cartilage and enclosed by a strong fibrous capsule that is lined by synovial tissue. The outer fibrous capsule is reinforced by ligaments that act as primary stabilisers of the joint. The joint cavity is filled with lubricating synovial fluid that is synthesised by the synovial membrane and hyaline cartilage, allowing low-friction motion between the joint elements. The joint cavity may also contain fibrocartilage extensions of the capsule that function to spread load more evenly within the joint and act as a secondary stabiliser (knee menisci and hip labrum). Further stabilisation of the joint is provided by accessory ligaments that may be separate to, or fused with, the capsule.

Synovial joints perform a variety of movements, necessitating variation on the same basic design. These include pivot joints that allow rotation (upper cervical vertebra), hinge joints that allow movement in only 1 plane but can allow transfer of large forces to create great power (knee, elbow), saddle joints that allow fine multidirectional movement (small joints of the hand), plane joints that allow limited sliding motion whilst resisting large forces (midfoot), condyloid joints that allow complex composite movement (wrist), and ball and socket joints that can rotate and flex almost freely in any direction whilst maintaining great stability (shoulder, hip).

\section{An Overview of Synovial Joint Development}

Despite the heterogeneity of synovial joint morphology, common signalling pathways underpin their development. In this section, we give a brief overview of the process, although dedicated reviews of this topic can be found elsewhere $[12,13]$. Bones and joints develop in mesoderm, comprising mesenchymal cells that have the ability to differentiate into fibroblasts, chondroblasts or osteoblasts and the blood vessels and connective tissues of the limb.
Synovial joint formation begins at approximately week 7 of embryogenesis as interzonal mesenchyme between the developing bones [14]. Figure 1 shows joint development from mouse data, but the same stages are followed in humans. The outer layers of the interzone form the long bone epiphyses through endochondral ossification [15], whilst the inner layer differentiates into the articular surfaces. Removal of the interzonal mesenchyme during embryonic development results in fusion of the adjacent developing bones [16].

At the molecular level, the appearance of the interzone is accompanied by a decrease in type II collagen expression [17], and an increase in growth differentiating factor 5 (GDF5) and bone morphogenetic protein 2 (BMP2) expression. GDF5, a member of the transforming growth factor beta superfamily [18], is a key early marker of interzone development and segmentation of skeletal elements [19, 20]. Gdf5 knockout results in failure of synovial joint development in mice [20]. Whilst GDF5 is an essential requirement for joint development, it is not specific to synovial joints, and its over-expression also results in failure of joint formation, increase in size of the skeletal elements and over-proliferation of epiphyseal cartilage [21].

Interzone expression gradients of BMPs and their inhibitors Noggin and Chordin also regulate appropriate synovial joint development [22, 23]. Relative BMP over-expression results in an epiphyseal cartilage phenotype and joint fusion, rather than in hyaline cartilage and normal joint development. Synovial joint development is also critically dependent upon wingless (wnt) 4 , wnt9a, and wnt 16 signalling within the interzone [24]. Whilst wnt signalling is not a requirement for joint initiation, it is a requirement for proper development, including the formation of hyaline articular cartilage. Wnt4 and wnt9a knockout does not inhibit joint patterning but results in subsequent fusion [24, 25]. The molecular regulation of early joint patterning is not limited to the interzone. Indian hedgehog ( $\mathrm{IHH})$, expressed at the growth plate during long bone formation, also modulates developing joint architecture and Ihh knockout is also characterised by joint fusion [26, 27].

Interzone formation is followed by a process of joint cavitation that involves limited cell death [28], alterations in fibrillar collagen from type I to type II [17], and differential growth of the joint elements as the clefts join to form the central synovial cavity, lined by the developing synovium and joint capsule [29]. The articular cartilage is formed by a layer of cells at the end of the epiphyseal growth plate [30]. Peripherally, the interzone mesenchyme gives rise to the fibrous joint capsule and supporting ligaments of the joint. Where the mesenchyme lines the capsule and articular surfaces, the mesenchymal cells form the synovial membrane. These cells subsequently disappear from the articular cartilage surface, probably as a result of joint movement. 


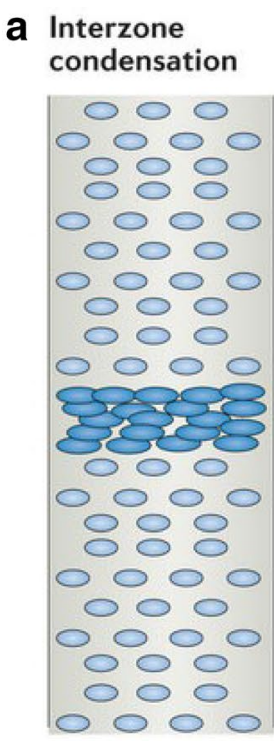

\section{b Joint specification}

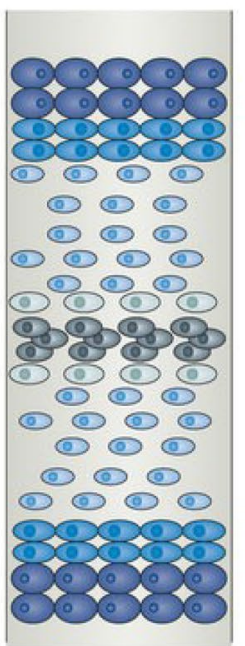

C Secondary structure induction and cavitation

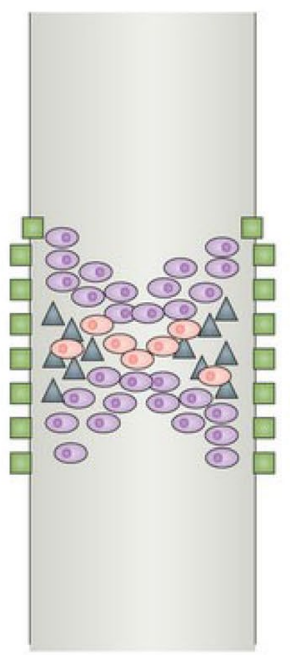

d Joint maturation

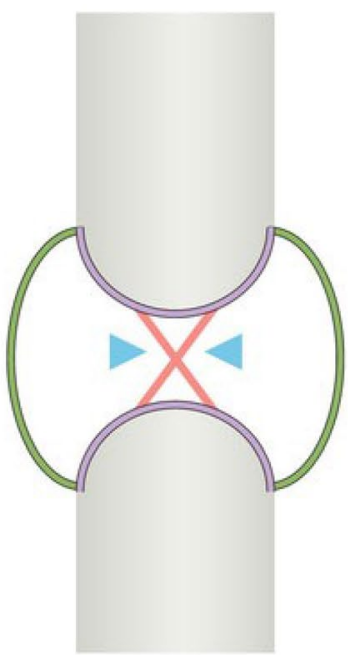

$\begin{array}{ll}\text { Col2a1 }^{+} & \text {Col2a } 1^{\mathrm{Neg}} \mathrm{Gdf} 5^{\text {High }} \\ \text { Interzone } & \text { Col2a } 1^{\mathrm{Lo}} \mathrm{Gdf} 5^{\text {High }} \\ & 0 \text { Proliferative chondrocyte } \\ & 0 \text { Prehypertrophic chondrocyte } \\ & \text { Hypertrophic chondrocyte }\end{array}$

Fig. 1 Synovial joint development in the mouse. Longitudinal views depicting key steps in the formation of the knee joint. a The first sign of a presumptive joint is a condensation of $\mathrm{Col} 2+\mathrm{limb}$ bud progenitors at the presumptive joint site; $\mathbf{b}$ Joint specification is marked by induction of Gdf5 in the interzone and downregulation of Col2a1; c
A joint space is formed by cavitation after progenitors for a variety of secondary joint structures are specified from the Gdf5+ progenitor pool; d Maturation of the synovial joint of the knee occurs during development and early postnatal life. Reproduced from Salazar et al. [165], with permission
The process of joint cavitation is thought to occur largely through mechanically induced changes in the extracellular matrix [30, 31]. Although interzone formation occurs in the absence of movement, skeletal muscle activity is required for both cavity formation and subsequent morphogenesis [14, 32-34]. During this period there is also an increase in expression of CD44 and increased hyaluronan synthesis that facilitates tissue separation and formation of a functional cavity [35], which is also thought to be under mechanical regulation [36]. Studies show that muscle imbalance during development results in abnormally shaped joints [37-39]. There is also evidence that some signalling mechanisms may be joint-specific [20, 40]. An overview of the signalling networks involved in synovial joint development and their spatial colocation is shown in Fig. 2 (adapted from [12]). Joint growth and modelling continues beyond embryogenesis and throughout postnatal growth to skeletal maturity. This growth is regulated by a complex interplay of local molecular mechanisms that are, in turn, also regulated at the long-range level [41]. These processes are reviewed in detail elsewhere, $[13,42]$ but where perturbed, joint shape
$\triangle$ Meniscal progenitor
Bone
Ligament progenitor
Meniscus
Synovial progenitor
Articular progenitor
- Ligaments
Synovium
ค Articular cartilage

and surface congruity abnormalities may result that can give rise to secondary OA.

In the following sections, we consider several common complex conditions in which joint development is affected preor post-natally. The evidence base for these conditions comes from the epidemiological literature that uses its own lexicon of terms. For the purposes of this review, we use the term "risk factors" to mean variables that affect an individual's chance of developing a disease. We use the term "susceptibility" to mean the individual's overall chance of developing the disease. Note that the associations between individual risk factors and overall disease susceptibility may be causal (in which there is a direct mechanistic link), or represent a marker for the disease for which the mechanism of the link is unclear but the two are clearly associated (such as through a third factor). The terms variant and single nucleotide polymorphism (SNP) are used synonymously. We use the term "common variant" to describe risk alleles with a frequency of $>5 \%$ (or 0.05). Low-frequency variants have an allele frequency of between 1 and $5 \%(0.01$ to 0.05 ), and rare variants have a frequency of $<1 \%$ (or 0.01 ). 


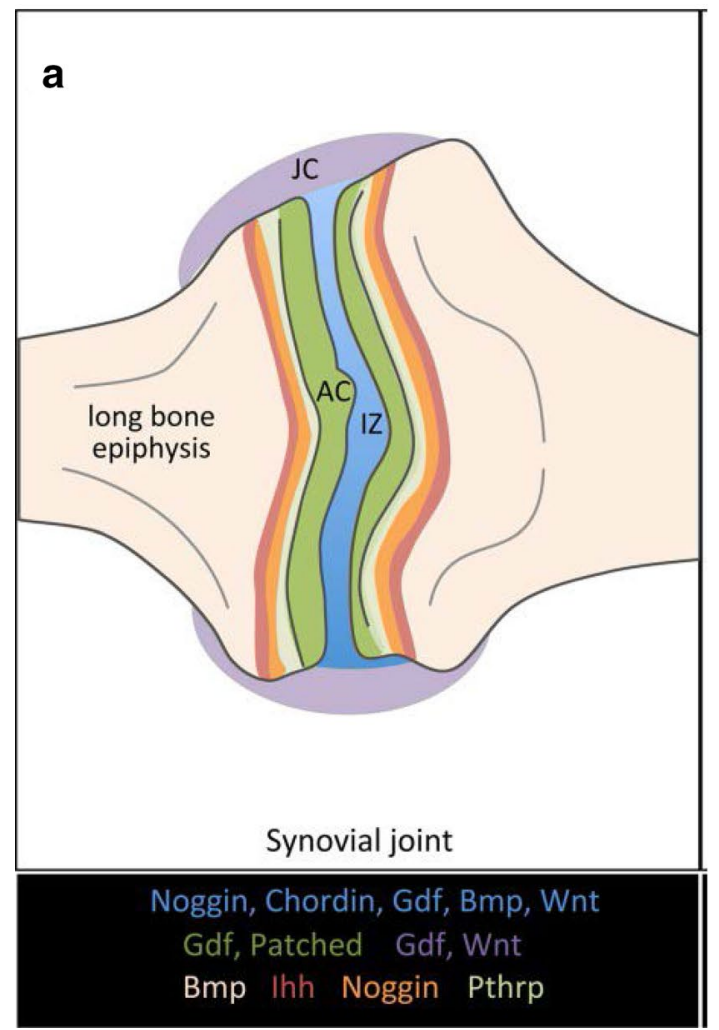

Fig. 2 Spatial expression patterns (a) and principal signaling pathways (b) in synovial joint development. The expression domains of critical signalling pathway components are regionally restricted dur-

\section{How Does Genetic Variation Influence Joint Architecture?}

As outlined above, it is clear that a complex interplay of molecular signalling and mechanical events are required for normal synovial joint development. Whilst loss of function mutations within genes critical to synovial joint morphogenesis lead to generalised musculoskeletal skeletal abnormalities that may be incompatible with life, polymorphisms that arise in viable general populations also give rise to variations in joint shape that are heritable. The former group comprises a multitude of genetic mutations that provide critical insights into the functioning of individual genes required for normal musculoskeletal development. Here, we focus on common, complex disorders that arise within general populations and associate with the development of OA. These disorders may be broadly classified into those that are captured within established disease definitions, and those that represent statistical shape variation within populations.

The hip is the most common site for established pathological variation in joint shape. Recognised disorders of hip joint morphology during growth include developmental dysplasia of the hip (DDH), Perthes' disease, slipped capital femoral epiphysis (SCFE) and femoroacetabular ing development of synovial joints. $A C$ articular cartilage, $I Z$ interzone, $J C$ joint capsule. Reproduced from Salva et al. [12], with permission

impingement (FAI). These diseases describe discrete pathological entities that are associated with specific clinical shape phenotypes.

\section{Developmental Dysplasia of the Hip}

$\mathrm{DDH}$, the most common skeletal dysplasia, is characterised by abnormal development of the hip joint and presents with varying severity from mild uncovering of the femoral head to complete dislocation of the hip joint and acetabular aplasia (Fig. 3a) [43]. DDH has an incidence that ranges from 0.06 per 1000 live births in individuals of African ancestry to 76.1 per 1000 live births in Native Americans, and with an incidence in the UK European population of 3.6 per 1000 [44]. The aetiology of DDH is complex, involving both environmental and genetic risk factors. Known associations include female sex, first-born, breech presentation, and family history [44].

Family studies have demonstrated that heritable factors contribute between 50 and $85 \%$ of the total DDH susceptibility [45-47]. Stevenson et al. [48], in a familial aggregation study of 1649 distinct individuals from Utah, USA, with a DDH case: control ratio of 1:10, found a recurrent risk of 12 in first-degree relatives of those with DDH versus controls. 

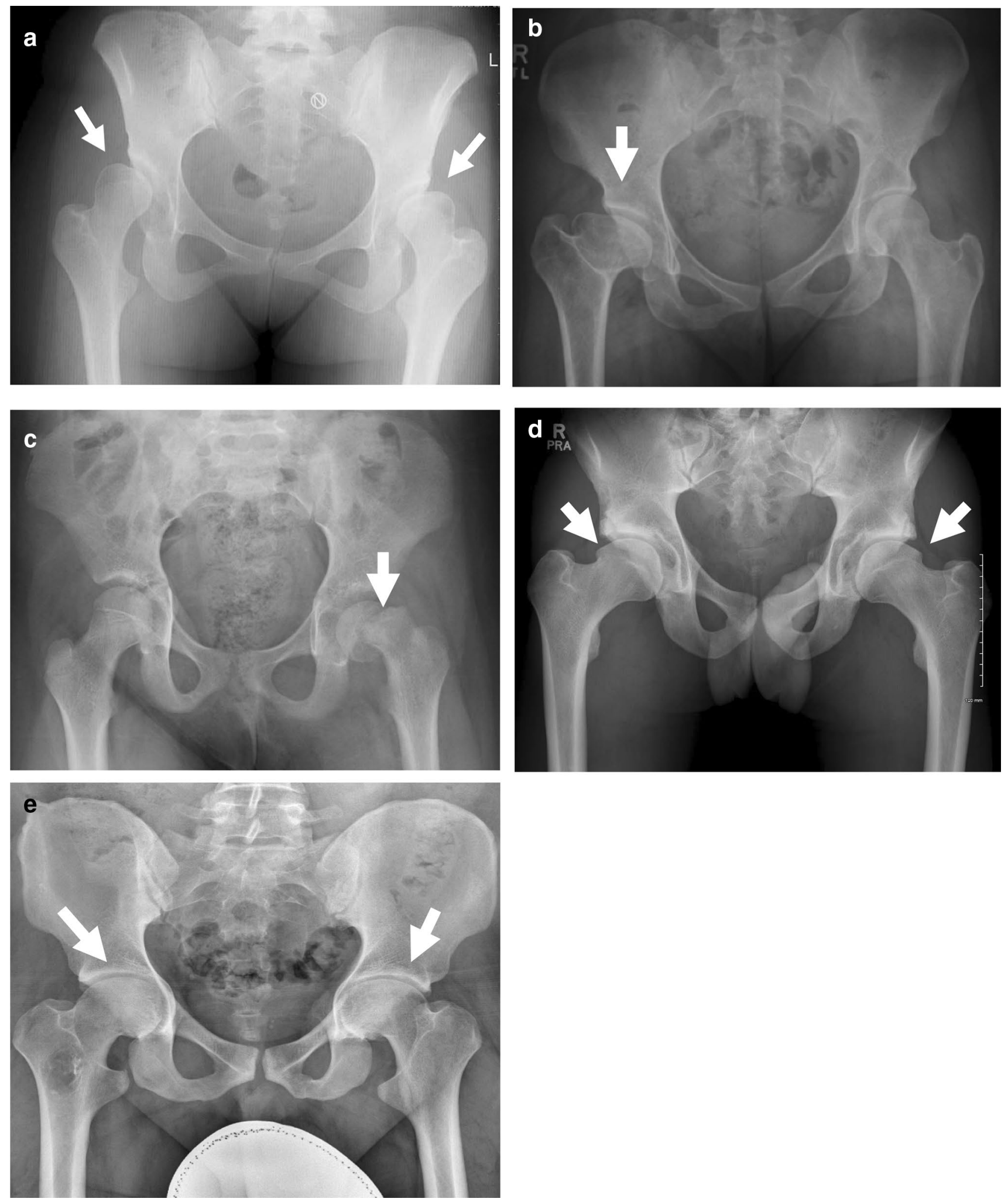

Fig. 3 Disorders of the growing hip joint. a Bilateral hip dysplasia in a skeletally mature individual. The acetabuli are typically shallow and steep, and there is extrusion of the femoral heads with evidence of decreased lateral coverage (arrows); b Perthes' disease of the right hip in a skeletally mature individual. The right femoral head is broad and flattened and the corresponding acetabululm is similarly shaped

(arrow). c Slipped capital femoral epiphysis of the left hip in an adolescent male. The epiphysis has slipped posteromedially from the physis (arrow); d Bilateral cam lesions in a skeletally maturing male, arrows show lateral head-neck junction prominence; e Bilateral pincer lesions in a skeletally mature male, arrows show over-coverage of femoral head 
Li et al. [46], in a case-control familial study of Chinese individuals with DDH, reported a heritability of $84 \%$, and a sibling recurrent risk of probands that was tenfold that of the siblings of controls. Heritability may also be estimated at the population level amongst unrelated individuals using genome-wide association study (GWAS) analysis approaches. Hatzikotoulas et al. [49], using genetic complex trait analysis [50] across 770 DDH cases and 3,364 controls in a discovery scan of 257,000 directly typed genetic variants with a minor allele frequency of $>0.01$, found that common variants explained 55\% of the liability-scale heritability, and was equally distributed across chromosomes.

Genome-wide linkage analysis (GWLA) has identified several chromosomal regions segregating within large DDH pedigrees. Feldman et al. [51], in a GWLA on an 18-member multigeneration family, the proband of which was severely affected by DDH, identified a $4 \mathrm{Mb}$ region on chromosome 17q21. Candidate genes coded in this region are the $H O X B$ cluster of homeobox genes, COL1A1 and DLX3. A Japanese GWLA of a 4-generation family containing eight patients with familial osteoarthritis of the hip associated with acetabular dysplasia suggested linkage at 13q22 [52]. A GWLA of a large South African family of European origin with Beukes hip dysplasia, an autosomal dominant disorder of variable penetrance that is characterised by bilateral dysmorphism of the proximal femur, mapped the causal gene to a $3.34 \mathrm{Mb}$ region at $4 \mathrm{q} 35$ [53]. Several candidate gene studies have also suggested associations between genetic variants and DDH, including GDF5, TBX4, ASPN, and IL6, although only $G D F 5$ has been independently replicated and reached genome-wide statistical significance levels (Table 1).

Genome-wide association analysis enables a hypothesisfree approach to interrogating the entire human genome for potential associations with a disease. In a GWAS of 770 DDH cases and 3364 population-based controls, Hatzikotoulas et al. [49] identified eleven correlated variants at genome-wide significance $\left(P<5.0 \times 10^{-8}\right)$ residing within the 5'untranslated region of GDF5 (20q11.22). Independent signals were replicated in three DDH cohorts of UK European ancestry, totalling 1129 cases and 4652 controls. Following meta-analysis, rs 143384 in GDF5 (OR [95\% CI] 1.44 [1.34-1.56], $P=3.55 \times 10^{-22}$ ) was robustly associated with $\mathrm{DDH}$, reaching genome-wide significance in both the discovery and the replication cohorts. Gene-based association analysis in this cohort also implicated variation within UQCC1, MMP24, and RETSAT at $P<5 \times 10^{-8}$. UQCC1 lies adjacent to $G D F 5$ and encodes a trans-membrane protein ubiquinol-cytochrome-c reductase complex chaperone. $U Q C C$ is expressed in differentiating chondrocytes and regulates growth control $[54,55]$. Variants in this gene are also associated with bone size [56], height [57] and hip axis length [58]. MMP24 encodes a member of the peptidase M10 family of matrix metalloproteinases that are involved in the breakdown of extracellular matrix in embryonic development and tissue remodelling [59]. Sequence variants within MMP24 have also been associated with childhood height [60, 61]. RETSAT codes for retinol saturase, an enzyme centrally involved in the metabolism of vitamin A [62]. Retinoic acid signalling is essential for normal limb bud development, including bone and cartilage formation [63]

\section{Perthes' Disease}

The term Perthes' disease describes idiopathic osteonecrosis of the femoral head in children. Depending upon the age of onset and the capacity of the developing hip to remodel, the disease results in femoral head and acetabular shape abnormalities of varying severity (Fig. 3b). Perthes' disease varies greatly in incidence between geographic areas and ethnic groups, but in Western European populations the prevalence is typically between 5 and 15 per 100,000 children under the age of 15 years [64]. The condition is thought to have a multifactorial inheritance pattern, with a sibling and offspring recurrent risk of $2.6 \%$ in the UK, based upon the family history of 412 index cases [65]. In a recent study using the Danish Twin Register, Metcalfe et al. examined 81 twin pairs [66] and identified a familial clustering but no genetic component, with an overall proband concordance of 0.09 . Although several small case control association studies of the disease have been conducted, including a meta-analysis of hypercoagulability genetic polymorphisms totalling 824 cases and 2033 controls [67], only variation within Factor V Leiden thrombophilia (an inherited disorder of blood clotting) was identified as a possible risk locus (pooled OR 3.10 [95\% CI 1.68-5.72]) [67]. Thus, although geographic and familial clustering is clear in Perthes' disease, the genetic component appears to be small. However, this may be due to the limited sample size and hence power of studies to date.

\section{Slipped Capital Femoral Epiphysis}

Slipped capital femoral epiphysis (SCFE) is a disorder of the hip that is characterised by displacement of the capital femoral epiphysis from the metaphysis through the physis, and results in a characteristic shape abnormality of the hip joint (Fig. 3c). It is a disorder of the adolescent developing hip, is more common in males, and has an incidence that is similar to that of Perthes' disease [68]. The condition is thought to have an endocrine aetiology and can cluster in families [69, 70], but to date, powered studies to determine any heritable component have not been conducted.

\section{Femoroacetabular Impingement}

The term FAI describes morphological abnormalities of the femoral head-neck junction, acetabulum, or both, resulting 
Table 1 Summary of the published genetic associations with DDH

\begin{tabular}{|c|c|c|c|c|c|c|}
\hline Study reference & Gene/loci & $\begin{array}{l}\text { Chromosomal } \\
\text { location }\end{array}$ & Study design & SNP variant & Phenotype & Study population(s) \\
\hline $\begin{array}{l}\text { Feldman et al. } \\
\text { (2010) [51] }\end{array}$ & $17 \mathrm{q} 21.31-17 \mathrm{q} 22$ & $17 \mathrm{q} 21.31-17 \mathrm{q} 22$ & GWLA & - & $\mathrm{DDH}$ & $\begin{array}{l}\text { American and } \\
\text { Chinese }\end{array}$ \\
\hline $\begin{array}{l}\text { Mabuchi et al. } \\
\text { (2006) [52] }\end{array}$ & $13 q 22$ & $13 q 22$ & GWLA & - & $\mathrm{DDH}$ & Japanese \\
\hline $\begin{array}{l}\text { Watson et al. } \\
(2015) \text { [53] }\end{array}$ & $U F S P$ & $4 q 35$ & $\begin{array}{l}\text { GWLA and exome } \\
\text { sequencing }\end{array}$ & c. $868 \mathrm{~T}>\mathrm{C}$ & $\begin{array}{l}\text { Beukes hip dys- } \\
\text { plasia }\end{array}$ & South African \\
\hline $\begin{array}{l}\text { Feldman et al. } \\
\text { (2013) [153] }\end{array}$ & $C X 3 C R 1$ & $3 \mathrm{p} 22.2$ & $\begin{array}{l}\text { GWLA and exome } \\
\text { sequencing }\end{array}$ & rs3732378 & $\mathrm{DDH}$ & American \\
\hline $\begin{array}{l}\text { Basit et al. (2017) } \\
\text { [154] }\end{array}$ & $H S P G 2$ & p. Ala1110Ser & $\begin{array}{l}\text { GWLA and exome } \\
\text { sequencing }\end{array}$ & c. $3328 \mathrm{G}>\mathrm{T}$ & $\mathrm{DDH}$ & Saudi Arabian \\
\hline $\begin{array}{l}\text { Basit et al. (2017) } \\
\text { [154] }\end{array}$ & $A T P 2 B 4$ & p. Arg755Gln & $\begin{array}{l}\text { GWLA and exome } \\
\text { sequencing }\end{array}$ & c. $2264 \mathrm{G}>\mathrm{A}$ & $\mathrm{DDH}$ & Saudi Arabian \\
\hline $\begin{array}{l}\text { Dai et al. (2008) } \\
\text { [155], and } \\
\text { Hatzikotoulas } \\
\text { et al. (2018) [49] }\end{array}$ & GDF5 & $20 q 11.22$ & $\begin{array}{l}\text { CGAS } \\
\text { GWAS and subse- } \\
\text { quent replication }\end{array}$ & $\begin{array}{l}\text { rs143383, } \\
\text { rs143384 }\end{array}$ & $\begin{array}{l}\mathrm{CDH} \\
\mathrm{DDH}\end{array}$ & $\begin{array}{l}\text { Chinese females } \\
\text { United Kingdom }\end{array}$ \\
\hline $\begin{array}{l}\text { Wang et al. (2010) } \\
\text { [156] }\end{array}$ & $T B X 4$ & $17 \mathrm{q} 23.2$ & CGAS & rs 374448 & $\mathrm{DDH}$ & Chinese \\
\hline $\begin{array}{l}\text { Shi et al. (2011) } \\
\text { [157] }\end{array}$ & $A S P N$ & $9 \mathrm{q} 22.31$ & CGAS & $\begin{array}{l}\text { D-repeat polymor- } \\
\text { phism of ASPN }\end{array}$ & $\mathrm{DDH}$ & Chinese \\
\hline $\begin{array}{l}\text { Cengic et al. } \\
\text { (2015) [158] }\end{array}$ & IL6 & $7 \mathrm{p} 15.3$ & CGAS & rs1800796 & $\mathrm{DDH}$ & Croatian \\
\hline $\begin{array}{l}\text { Cengic et al. } \\
\text { (2015) [158] }\end{array}$ & $T G F B 1$ & $19 \mathrm{q} 13.2$ & CGAS & rs 1800470 & $\mathrm{DDH}$ & Croatian \\
\hline $\begin{array}{l}\text { Jia et al. (2012) } \\
\text { [159] }\end{array}$ & РАPPA2 & $20 \mathrm{q} 11.22$ & CGAS & rs 726252 & $\mathrm{DDH}$ & Chinese \\
\hline $\begin{array}{l}\text { Hao et al. (2014) } \\
\text { [160] }\end{array}$ & НОХВ9 & $17 q 21.32$ & CGAS & rs2303486 & $\mathrm{DDH}$ & Chinese \\
\hline $\begin{array}{l}\text { Tian et al. (2012) } \\
\text { [161] }\end{array}$ & HOXD9 & $2 \mathrm{q} 31.1$ & CGAS & rs711819 & $\mathrm{DDH}$ & Chinese females \\
\hline $\begin{array}{l}\text { Liu et al. (2014) } \\
\text { [162] }\end{array}$ & $D K K 1$ & 10q21.1 & CGAS & rs1569198 & DDH & Chinese \\
\hline $\begin{array}{l}\text { Zhao et al. (2013) } \\
\text { [163] }\end{array}$ & COL1A1 & $17 \mathrm{q} 21.33$ & CGAS & rs113647555 & DDH & Chinese females \\
\hline $\begin{array}{l}\text { Sun et al. (2015) } \\
\text { [164] }\end{array}$ & UQCC & $20 \mathrm{q} 11.22$ & GWAS & rs6060373 & $\mathrm{DDH}$ & Chinese \\
\hline
\end{tabular}

GWLA genome-wide linkage analysis, CGAS candidate gene association study, GWAS genome-wide association study

in abnormal contact between the proximal femur and the pelvic acetabulum at the hip joint [71]. Two basic pathologies are described. In "Cam" morphology, a non-spherical extension of the femoral head-neck junction (usually anterolateral) causes abutment into the adjacent acetabular cavity [72] (Fig. 3d). In "Pincer" morphology, local or global over-coverage of the acetabulum results in linear impact of the acetabular rim against the head-neck junction [73] (Fig. 3e). The two deformities may also coexist in "Combined" lesions. The FAI hip shape abnormality develops during the adolescent phase of skeletal growth before closure of the growth plate and has been associated with higher levels of sporting activity [74], although a causal link to exercise remains unclear. Asymptomatic FAI is highly prevalent (estimated at up to 75\%) in populations of European descent (with cam lesions being more common in males) but is rare in Asian populations [75-78].

The heritable basis of FAI as a distinct hip shape abnormality has not yet been studied in depth. This is perhaps unsurprising, as its development can only be definitively determined at closure of growth plate [79], and there are few clinical reasons to image the hip in asymptomatic young adults. However, small-scale analyses do exist. Pollard et al. compared 96 siblings (mean age 38 years) of 64 patients (mean age 36) treated for FAI with a spouse control group of 77 individuals (mean age 42) and found a relative risk of cam morphology of 2.8 (95\%CI 1.8-4.2) and of pincer morphology of 2.0 (1.3-3.0). Pollard et al. also examined 
familial associations in 'sibkids' [80], a cohort with a hereditary predisposition to hip osteoarthritis, and estimated an odds ratio for cam morphology of 2.1 (1.3-3.5) versus spouse controls but no differences in pincer morphology or dysplasia. However, subjects were examined in mid-life when degenerative change is prevalent and a possible common environment underpinning of the associations were not examined. To date, no well-powered genome-wide or candidate variant analyses have been published that examine the relationship between specific genetic risk factors and conventional radiographic indices of FAI.

\section{Population Level Variation in Joint Shape}

At the population level, computer vision methods have been applied to examine joint shape variation, although these phenotypes do not directly map to the clinical diagnoses of FAI or DDH. Statistical shape analysis describes the shape of a deformable object by applying principal component analysis to a set of landmark points, and assumes each shape is a deformed version of a reference shape. Statistical shape models (SSM) may be applied to both 2-dimensional (2-D) and 3-D medical images [81]. SSMs have been used to describe the principal sources of population variation in shape at both the hip and the knee [82-85], and to describe those associated with trochlear dysplasia [86] and acute anterior cruciate ligament injury [87]. In the setting of FAI, SSMs have also been used to compare cam lesion deviation from the population reference femoral head-neck shape in pre-operative planning for surgical intervention [88].

The epidemiology of bone geometry has been of interest in the exploration of the association between hip shape and osteoporotic fracture risk. In meta-analyses of overlapping patient cohorts, Baird et al. [89], and Hsu et al. [90] examined genome-wide genotyped datasets in patients with DXA scans of the hip to identify relationships with proximal femoral SSMs and conventional measures of hip geometry, respectively. Baird et al. used SSMs to examine shapegenotype associations in $\sim 16,000$ individuals across $\sim 7$ million SNPs, identifying eight independent genome-wide significant variants (Bonferroni-corrected $P<5 \times 10^{-9}$ ) that were associated with three modes of joint shape variation [89]. Seven of the variants were located within $200 \mathrm{~kb}$ of genes involved in endochondral ossification (SOX9, PTHrP, RUNX1, NKX3-2, FGFR4, DICER1, and HHIP), suggesting possible association with bone formation and by extension, joint shape. Hsu et al. examined conventional DXAderived hip structural analysis in 18,719 men and women. Using linkage disequilibrium (LD) score regression [91], they found that nominally-associating variants explained $12 \%, 13 \%, 18 \%$, and $22 \%$ of the heritable variation in neckshaft angle, femoral neck length, neck section modulus, and narrowest neck width, respectively. Following replication in independent cohorts, independent variants near IRIX/ ADAMTS16, LRP5/PPP6R32/GAL, CCDC91, FGFR4, $N S D 1$, and $R A B 24$ met genome-wide significance.

In a GWAS of bone area as a proxy for bone size quantitated by DXA, Styrkarsdottir et al. identified 12 loci that are associated with hip or vertebral size [92], examining 33.4 million sequence variants in Icelandic subjects across 28,954 hip scans and 29,059 lumbar spine scans. They identified rs143384 (20q11.22) in the GDF5 5'UTR as a locus for total hip $\left(\beta=0.071, P=2.2 \times 10^{-22}\right)$ and trochanteric area $\left(\beta=0.071, P=1.1 \times 10^{-18}\right)$. This locus had previously been robustly associated with DDH in the GWAS by Hatzikotoulas et al. [49]. They also identified two other hip area loci, $17 \mathrm{q} 24.3$ in an intergenic region near $S O X 9$ (intertrochanteric area $\left.\beta=0.072, P=6.2 \times 10^{-18}\right)$ and $4 \mathrm{q} 31.21$ in the $5^{\prime} \mathrm{UTR}$ of HHIP (femoral neck area $\beta=0.054, P=8.4 \times 10^{-14}$ ), that had previously been associated with hip shape SSMs in the Baird GWAS meta-analysis [89].

\section{Joint Shape is an Important Risk Factor for OA}

\section{Conventional Measures of Joint Shape and OA Susceptibility}

It has long been recognised that pathological developmental abnormalities of the hip joint such as DDH, Perthes' disease, and SCFE commonly result in osteoarthritis and hip replacement [49, 93-95]. For example, individuals with mild DDH are 10 times more likely to develop OA compared with DDH-free controls [96]. It has only been more recently appreciated that subtle variations in joint shape also predispose to degenerative change. Such variations in joint shape are commonly measured on plain radiographs in clinical practice to describe joint geometry (see Fig. 4 for common indices and their definitions). Observations by Murray [97], and later by Solomon [98] and Harris [99], estimate that over $90 \%$ of individuals with idiopathic hip OA exhibit subthe variations in acetabular and proximal femoral shape that precede the degenerative process (Fig. 5). These deformities are highly prevalent in European populations and can result in a focal mechanical overload of articular cartilage, leading to subsequent OA [72, 73, 100]. Doherty et al. [101], in a study of plain anteroposterior radiographs of the hip in 965 OA cases and 1111 controls without radiographic OA, found the presence of cam morphology in at least 1 hip in $18 \%$ of cases versus $4 \%$ of controls (OR 6.95; 95\% CI 4.64-10.41). An abnormal femoral head-to-neck ratio was present in of $24 \%$ in cases versus $4 \%$ in controls (OR 12.01; 8.05-18.15). As the femoral head-to-neck ratio decreased, the presence of hip OA also rose. 

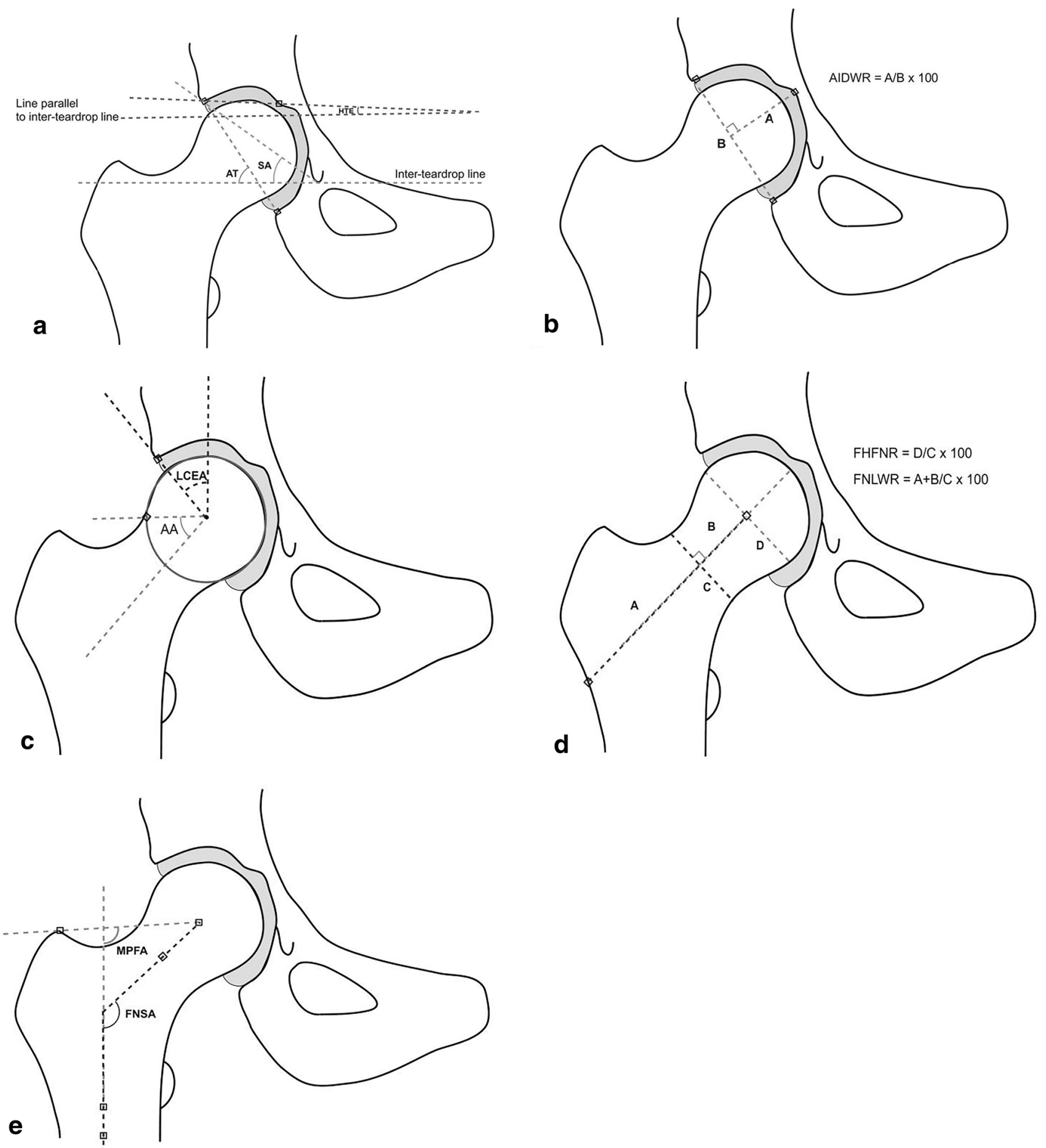

Fig. 4 Acetabular and proximal femoral morphological parameters associated with OA risk. a HTE horizontal toit externe, SA Sharp's angle, and $A T$ acetabular tilt; b AIDWR acetabular index of depth to width ratio; c $L C E A$ lateral centre-edge angle and $A A$ alpha angle; d

Demonstration that the converse is also true was made by Kim in 1989, reporting a high incidence of hip joint congruity and low incidence of both DDH and of OA in the Korean population [102]. Dudda et al. [103], compared

FHFNR femoral head to femoral neck ratio and FNLWR femoral neck length to width ratio; e MPFA modified proximal femoral angle and FNSA femoral neck-shaft angle

morphological features associated with FAI in females from a Chinese cohort (Beijing OA Study) versus white women from the United States participating in the Study of Osteoporotic Fractures. They found low lateral centre-edge angles 


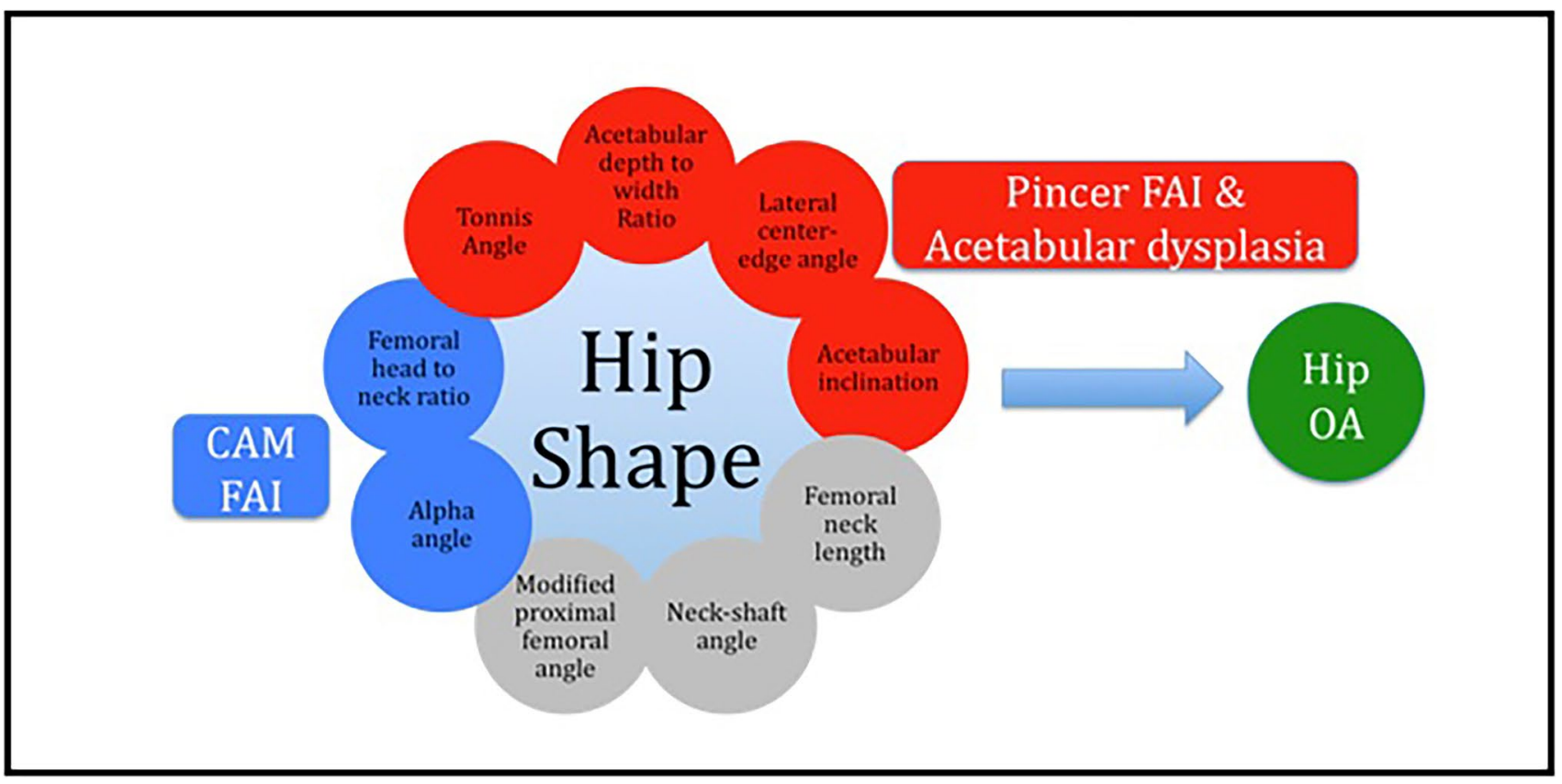

Fig. 5 The biomechanical consequences of non-normal hip shape. Illustration shows relationship between out of range hip shape parameters and the development of osteoarthritis

suggesting dysplasia $\left(<20^{\circ}\right)$ more often in the Chinese $(22 \%$ of hips versus $7 \%$ in whites, $p=0.005$ ), whilst low mean impingement angles $\left(83.6^{\circ}\right.$ versus $\left.87.0^{\circ}, p=0.03\right)$ and lateral centre-edge angles suggestive of impingement $(23 \%$ versus $11 \%, p=0.008$ ) were more common in women of European descent. More recently, Edwards et al. examined hip plain radiographic morphological characteristics in individuals of European descent, African Americans and Chinese men and women with no radiographic hip OA [104]. They found that the Chinese group had more shallow and narrow acetabular sockets, reduced femoral head coverage, smaller femoral head diameter, and a lesser femoral neck-shaft angle versus the other ethnic groups. Taken together, these findings are consistent with the epidemiological observation that idiopathic OA is more prevalent in Europeans [105], whilst in Asian populations hip OA is more commonly associated with a DDH morphology.

Deformities associated with cam-type FAI and subtle DDH morphology are also independent predictors of incident radiographic OA and progression to hip replacement in longitudinal studies. Nicholls et al. [106], found that cam morphology, identified by an alpha angle of greater than $65^{\circ}$, had an increased risk of radiographic OA and hip replacement over 2 decades [107], with each degree increase in alpha angle conferring a 5\% and 3\% increase in risk respectively. Agricola et al. found similar relationships between increasing alpha angle (>cam morphology) and OA progression in the CHECK cohort [108]. Thomas et al. [107], found that mild DDH increased the risk of radiographic OA development and hip replacement over 2 decades, with each degree reduction in lateral centre edge angle below $28^{\circ}$ associated with a $14 \%$ and $21 \%$ increase in risk of OA and hip replacement, respectively [107]. However, no clear associations have been identified between isolated pincer-type FAI and future OA risk [106-109].

\section{Statistical Models of Joint Shape and OA Susceptibility}

SSMs capture information that is predictive of OA and that is not present in predefined radiographic geometric measures, and vice versa. When combined, they add to the predictive value for incident OA above clinical risk factors. Waarsing et al. [110], examined DXA images of the hip in 218 men and women with established hip OA followed over 2 years. They demonstrated that various shape and texture modes correlated with clinical pain and function scores where plain radiographic measures (Kellgren-Lawrence (KL) score and minimum joint space width) did not. Castaño-Betancourt et al. [111], used SSMs and predefined geometry parameters derived from baseline plain hip radiographs to predict incident radiographic OA (KL score $\geq 2$ ) over 6.5 years in 688 individuals from the Rotterdam Study. They found that hip geometry alone was of similar predictive value to clinical risk factors of sex, age, and body mass index; and when combined, added $7 \%$ to the prediction obtained by clinical risk factors alone (AUC $=0.67$ (geometry), 0.66 (clinical), 0.73 (geometry + clinical) [111]. Agricola et al. demonstrated in 
female participants in the CHECK and Chingford cohorts that baseline $(\mathrm{KL}<2)$ radiograph-derived hip SSMs were also associated with future THR [112].

SSMs are also emerging as a useful phenotyping tool to improve our understanding of the relationship between genotype and joint shape. In the first of such studies, BakerLePain et al. [113], examined the association of candidate variants within the wnt antagonist $F R Z B$ with radiographderived hip shape SSMs in a nested subsample (Europeanancestry women $\geq 65$ years; 451 hip OA cases, 601 controls) from the Study of Osteoporotic Fractures. They found no association between genotype and case-control status or with acetabular depth or centre edge angle, but a weak association with mode 2 (amongst 10 modes) in subjects having at least 1 copy of the rs 288326 or the rs 7775 FRZB minor allele ( $P=0.019$ for each test). A subsequent analysis stratified by presence of the rs 288326 minor allele showed a weak positive association between the upper quartile of subjects for mode 2 with OA in those carrying the variant allele $(P=0.02)$, which led them to propose that genetic variation within $F R Z B$ may modulate the effect of hip shape on OA risk.

Subsequently, Lindner et al. examined 41 candidate genetic variants (that had previously been associated with OA or hip morphology) and plain anteroposterior radiographs of the non-OA-affected hip in 929 patients from the arcOGEN cohort $[114,115]$. In univariate analysis they identified an association between rs4836732 (within ASTN2) and mode 5 of the female SSM $(p=0.0016)$, and between rs6976 (within GLT8D1) and mode 7 of the mixed sex SSM $(p=0.0003)$. The multivariate analysis identified association between rs5009270 (near IFRD1) and a combination of modes 3, 4, and 9 of the mixed-sex SSM ( $p=0.0004)$. In the Baird et al. hip shape GWAS [89], 3 of the genome-wide significant variants that were associated with shape mode variation are also established loci for hip OA, rs4836732 (intronic variant within ASTN2), rs10743612 (intergenic variant downstream of $P T H L H$ ), and rs73197346 (intergenic variant upstream of $R U N X 1$ ).

Fewer studies have examined the relationship between SSMs and knee OA. Haverkamp et al. examined differences in knee shape by SSMs between women with prevalent knee OA versus those without OA in Rotterdam Study participants [116]. They found that the women with knee OA had SSMs that described a broader femur and tibia and also an elevated lateral tibial plateau, findings that are consistent with plain radiographic features in the presence of knee OA. Wise et al. [117], in a study of 304 knees with $(K L \geq 2)$ versus 304 knees without $(K L<2)$ incident $\mathrm{OA}$ from the Osteoarthritis Initiative found that SSMs of distal femoral and proximal tibial shape derived from plain anteroposterior knee radiographs only weakly and inconsistently modulated the relationship between sex and incident knee OA.

\section{Bone Shape Remodelling in Response to OA}

Care is required when interpreting the results of joint shape and OA susceptibility association analyses, as joint shape changes with OA severity. Gregory et al. [118] used SSMs of the proximal femur derived from plain radiographs of the hip at baseline and again after 6 years in 110 participants in the Rotterdam Study to quantify the deforming effect of OA progression on the proximal femur, and first proposed SSMs as an imaging biomarker of hip OA progression. Similarly, Hunter et al. [119], conducted a nested case-control study of knee MRI data within the Osteoarthritis Initiative and showed that bone area increased and shape changed more over 24 months in OA cases versus controls (OR case/ control 1.28-1.71 for area, and 1.22-1.64 for shape per SD change in each variable, respectively).

Such observations make the disentangling of causation from association challenging, particularly where low-resolution modalities such as DXA are used in isolation to define the joint shape and absence of OA at baseline. Further, DXA images present a distorted image of the hip that is magnified in the $x$-axis, because of the fan-beam image acquisition [120]. These limitations are not confined to DXA data, but may impact all SSMs based on 2-D imaging. For example, as OA progresses at the hip, fixed external rotation of the hip occurs that may also give the impression of a change in bone area or femoral neck-shaft angle. Similarly, femoral head osteophytes lead to high alpha angles seen in Cam morphology, and lateral acetabular osteophytes produce pincer morphology. Cross-sectional imaging modalities do not suffer such artefacts to the same extent. Recently, Inamdar et al. [121] conducted a 36-month longitudinal MRI study of variation in proximal femur 3D morphological shape (3DSSM) and associations with cartilage health in 46 men and women with developing hip osteoarthritis. They showed that 3D-SSM characterising increases in head and neck volume and decreasing femoral neck anteversion were weakly associated with progression of symptoms and MRI-identified cartilage lesions.

Bone remodelling features have also been used to define different phenotypes within established OA into normotrophic, hypertrophic, or atrophic, depending upon the resultant bone shape [122]. These differences in bone remodelling responses may also have genetic correlates that further impact on the observed genetic relationships between joint shape and OA. Panoutsopoulou et al. [123], examined the effect of clinically relevant endophenotyping according to site of maximal joint space narrowing (maxJSN) and bone remodelling response in a stratified GWAS of the arcOGEN dataset, comparing 2118 radiographically-defined hip OA cases and 6500 population-based controls. They found that variation within $L R C H I$ was associated with site of maximal joint space narrowing (OR $0.70 ; 0.61-0.80$ ), whilst variation 
adjacent to $S T T 3 B$ was associated with a hypertrophic pattern of remodelling (OR 1.45; 1.24-1.69). Both associations were completely attenuated in the non-stratified analyses. Further, STT3B was over-expressed in OA-affected versus intact human cartilage in an analysis of hypertrophic versus atrophic bone remodelling pattern.

\section{Evidence from OA Susceptibility Studies}

Our understanding of the genetic epidemiology of OA has increased substantially over the last few years with the number of genome-wide scans reported on increasingly large patient cohorts. To date, these efforts have resulted in almost 100 robustly replicating genome-wide significant OA risk loci being identified [124-129]. The vast majority of these risk loci represent common variants with a small to moderate effect size, consistent with the complex and highly polygenic architecture of the disease (Fig. 6). However, large-scale GWAS datasets are not commonly accompanied by radiographic phenotype data upon which to examine relationships with joint shape.

Zengini et al. [124], in a GWAS of the UKBiobank metaanalysed with other cohorts totalling 30,727 cases and 297,191 controls examining 16.5 million variants identified nine novel, robust OA variants. They also conducted a nested substudy of osteoarthritis-related plain radiographic phenotypes in mixed cohorts of smaller size (where radiographic data were available). Of the nine identified variants in the primary analysis, several were associated with the minimum joint space width phenotype, but only a nominal association between an intergenic variant rs 116882138 and centre-edge angle (a feature of DDH, $\beta=-1.1388, P=0.03$ ), and no association with alpha angle (a feature of cam morphology), was found. Tachmazidou et al. [125], in the largest GWAS of OA published to date, including 77,052 cases and 378,169 controls in a meta-analysis examining 17.5 million variants, identified 64 signals (52 novel) at MAF $>0.01$ on top of 34 previously established loci [124, 126, 128, 130-142]. Pathways analysis using MAGMA, PASCAL, and DEPICT
Fig. 6 Effect size and risk allele frequency of published osteoarthritis genetic risk loci. Each circle represents a published osteoarthritis risk single-nucleotide variant plotted with its odds ratio (OR; $y$ axis) as a function of the risk allele frequency ( $x$-axis). The different size and colour of each circle shows the sibling relative risk ratio $(\lambda s)$ and the percentage of variance explained on the liability scale respectively $\left(h^{2} \mathrm{~L}\right.$; calculated assuming $13.5 \%$ prevalence of OA). Gene annotations are taken from the Ensembl genome browser (human assembly GRCh37). The majority are common variants with small $(\mathrm{OR}<2.0)$ effect sizes, only those with $\mathrm{OR}>2.0$ are named here

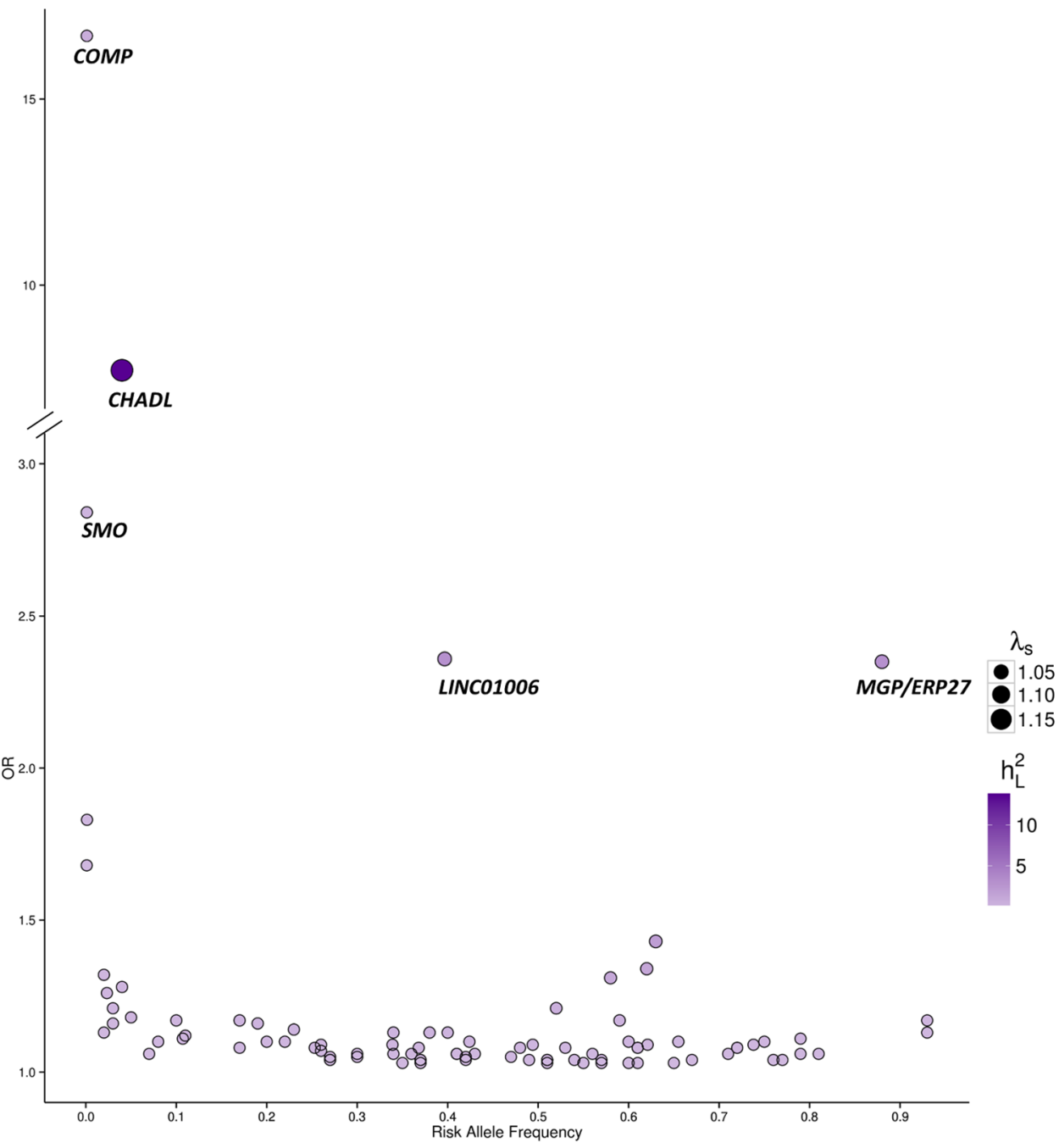


identified 64 biological processes, 46 of which are involved in bone, cartilage, or chondrocyte morphogenesis. Although associations with other demographic characteristics and disease states were examined by linkage disequilibrium regression analysis using LDHub [91], specific direct associations with joint shape were not explored.

\section{What Consistent Signals Arise from Both Joint Shape and OA Studies?}

Although many studies have examined the genetics of OA, relatively few have examined the genetics of diseases of joint shape or the relationships between shape, joint shape disorders and OA. Hatzikotoulas et al., used LD regression to estimate the genetic correlation between DDH and hip OA in the UK Biobank hip OA dataset, identifying a positive genetic correlation $(\mathrm{rg}=0.58$ (s.e. $=0.21), P=0.0047)$, but did not distinguish between a causal relationship versus shared genetic causes. Baird et al. [143], examined the relationship between 11 genetic loci for hip OA and DXAderived hip shape in 3111 women participating in the Avon Longitudinal Study of Parents and Children. They identified associations with at least nominal significance between 3 OA risk loci (KLHDC5/PHTLH rs10492367, DOT1L rs12982744, and COL11A1 rs4907986) and hip shape. Colocalisation analysis indicated sharing of genetic signals for hip shape and hip OA for the KLHDC5/PTHLH and COL11A1 loci. However, the cohort was not screened for the presence of radiographic OA prior to inclusion in the analysis and thus hip shape variation resulting from OA, rather than predisposing to it, cannot be excluded.

Whilst many risk loci that lie adjacent or within genes that have a role in mesenchymal cell function have been associated with subtle statistical variations in joint shape or OA susceptibility, relatively few specific genes have been consistently identified across both the joint shape and the osteoarthritis phenotypes. Some of the key implicated genes are outlined below.

Growth Differentiating Factor 5 (GDF5), a member of the TGF $\beta$ signalling family, is a key regulator of joint morphogenesis. Mutations in GDF5 results in brachydactyly and symphalangism [144]. Variation within GDF5 has also been widely associated with DDH [49], and also with hip osteoarthritis across multiple populations $[124,130]$. Pooled evidence for association from two independent Japanese studies attained genome-wide significance with allelic OR [95\%CIs] of 1.79 [1.53-2.09], $p=2 \times 10^{-13}$ [130]. This GDF5 SNP was later associated with knee OA in individuals of European descent in a subsequent meta-analysis across a total of $6861 \mathrm{knee}$ OA cases and 10,103 controls, with allelic OR [95\%CIs] of 1.16 [1.10-1.22], $p=9.6 \times 10^{-9}$ [145], and in hip and knee OA across 30,727 cases and 297,191 controls [124]. Chen et al. [146] have shown that the GDF5 locus contains many separate regulatory elements that control expression of the gene at different joint sites, and that these flanking regions are large. Capellini et al. of the same group have also recently described a novel enhancer region GROW1 in an extended downstream regulatory region of GDF5 [147]. Most recently, the same group has used chondrocyte chromatin datasets to propose a model linking evolutionary genetic variations within the GDF5-UQCC1 risk locus (rs6060369) that perturb regulatory constraint during knee development with subsequent knee OA in adult mice, and suggest an ortholog in chondrocyte evolution of the modern human knee that affects bone shape [148].

SOX9 is a pivotal transcription factor during joint development and in adulthood, committing mesenchymal progenitors to the chondrocyte lineage, activating cartilage-specific genes and modulating chondrocyte survival. SOX9 deficiency, generally due to spontaneous mutations at the $17 \mathrm{q} 24$ locus, causes campomelic dysplasia that is characterised by multiple long bone abnormalities, including brachydactyly and dislocation of the hips [149]. Common variation within SOX9 is associated with both OA and joint shape variation $[89,92,125]$. SOX9 lies within a relatively gene-free region on chromosome 17, with large domains (1.9 Mb upstream and $0.5 \mathrm{Mb}$ downstream) that facilitate interaction with cisacting elements causing SOX9-dependent diseases [150].

Parathyroid hormone-like hormone, encoded by PTHLH, regulates endochondral bone formation as a downstream signalling pathway to RUNX2, through its receptor's inhibitory action on chondrocyte development and differentiation and pro-osteoblastic activity [151]. Mutations in PTHLH cause brachydactyly and short stature [152], whilst common variation at the PTHLH locus is associated with hip shape and OA $[128,143]$.

Collagen type XI, encoded by COL11A1, is an important component of the growing skeleton, but its presence in the adult is mainly confined to articular cartilage and the intervertebral disc. Loss of function mutations In COL11A1 cause fibrochondrogenesis type 1 , a disorder characterised by severe skeletal abnormality and is usually fatal in early life; and Stickler and Marshall syndromes, disorders characterised by less severe bone and joint abnormalities that are non-fatal. Common variation in COL11Al is associated with hip shape variation and has been suggestively associated with hip OA, although not at genome-wide significance $[114,143]$. The molecular mechanisms of these proposed variants on COL11A1 expression remain to be clarified.

Astrotactin 2, encoded by ASTN2, is most strongly expressed in the brain and plays a role in neuronal migration. ASTN2 deletion causes autism and schizophrenia. Despite the apparent lack of relation to joint morphogenesis and $\mathrm{OA}$, common variation in ASTN2 is robustly associated with both hip shape and OA $[89,115,128]$. Although a proposed 
mechanism relating to pain sensing and OA symptomatology has been suggested, this does not readily explain the shape association.

Although variation in genes identified in the studies outlined above, including COL11A1, DOTIL, IHH, RUNXI, RETSAT, and many others may also link joint development with subsequent OA, they have not been specifically included here, as they are yet to be established with both phenotypes at genome-wide significance.

\section{Conclusions}

The study of increasingly large genome-wide meta-analyses together with multi-omics at scale, is starting to revolutionise our understanding of the heritable biology of osteoarthritis. We have established that $60 \%$ and $40 \%$ of susceptibility to hip and knee OA, respectively, is heritable. Current international initiatives, such as the GO Consortium https ://www.genetics-osteoarthritis.com/home/index.html will further expand the depth and breadth of our understanding of the contribution of common and low-frequency variants to disease heritability. Study of the heritable biology of joint shape, and how it relates to OA risk, thus far, is yet to benefit from the same advantages of scale and phenotype specificity. Advances have been made in understanding the contribution of hip shape to OA risk, and shape variation can be measured with varying degrees of accuracy by several methods. However, for OA at other sites including the knee, clear shape phenotypes are less readily identified. The influence of other risk factors, such as sex, obesity and joint injury at the knee also make establishing relationships between joint shape and genotype more complex. Future abilities to link relevant imaging data to clinical and genomic datasets will narrow this gap.

Open Access This article is licensed under a Creative Commons Attribution 4.0 International License, which permits use, sharing, adaptation, distribution and reproduction in any medium or format, as long as you give appropriate credit to the original author(s) and the source, provide a link to the Creative Commons licence, and indicate if changes were made. The images or other third party material in this article are included in the article's Creative Commons licence, unless indicated otherwise in a credit line to the material. If material is not included in the article's Creative Commons licence and your intended use is not permitted by statutory regulation or exceeds the permitted use, you will need to obtain permission directly from the copyright holder. To view a copy of this licence, visit http://creativecommons.org/licenses/by/4.0/.

\section{References}

1. Disease GBD, Injury I, Prevalence C (2016) Global, regional, and national incidence, prevalence, and years lived with disability for 310 diseases and injuries, 1990-2015: a systematic analysis for the Global Burden of Disease Study 2015. Lancet 388:1545-1602

2. Global Burden of Disease Study C (2015) Global, regional, and national incidence, prevalence, and years lived with disability for 301 acute and chronic diseases and injuries in 188 countries, 1990-2013: a systematic analysis for the Global Burden of Disease Study 2013. Lancet 386:743-800

3. Nuesch E, Dieppe P, Reichenbach S, Williams S, Iff S, Juni P (2011) All cause and disease specific mortality in patients with knee or hip osteoarthritis: population based cohort study. BMJ 342:d1165

4. Yelin E, Murphy L, Cisternas MG, Foreman AJ, Pasta DJ, Helmick CG (2007) Medical care expenditures and earnings losses among persons with arthritis and other rheumatic conditions in 2003, and comparisons with 1997. Arthritis Rheum 56:1397-1407

5. Murphy LB, Cisternas MG, Pasta DJ, Helmick CG, Yelin EH (2018) Medical expenditures and earnings losses among US adults with arthritis in 2013. Arthritis Care Res (Hoboken) 70:869-876

6. MacGregor AJ, Antoniades L, Matson M, Andrew T, Spector TD (2000) The genetic contribution to radiographic hip osteoarthritis in women: results of a classic twin study. Arthritis Rheum 43:2410-2416

7. Manek NJ, Hart D, Spector TD, MacGregor AJ (2003) The association of body mass index and osteoarthritis of the knee joint: an examination of genetic and environmental influences. Arthritis Rheum 48:1024-1029

8. Magnusson K, Turkiewicz A, Englund M (2019) Nature vs nurture in knee osteoarthritis - the importance of age, sex and body mass index. Osteoarthritis Cartilage 27:586-592

9. Griffin DR, Dickenson EJ, Wall PDH, Achana F, Donovan JL, Griffin J, Hobson R, Hutchinson CE, Jepson M, Parsons NR, Petrou S, Realpe A, Smith J, Foster NE, Group FAS (2018) Hip arthroscopy versus best conservative care for the treatment of femoroacetabular impingement syndrome (UK FASHIoN): a multicentre randomised controlled trial. Lancet 391:2225-2235

10. Palmer AJR, Ayyar Gupta V, Fernquest S, Rombach I, Dutton SJ, Mansour R, Wood S, Khanduja V, Pollard TCB, McCaskie AW, Barker KL, Andrade T, Carr AJ, Beard DJ, Glyn-Jones S, Group FS (2019) Arthroscopic hip surgery compared with physiotherapy and activity modification for the treatment of symptomatic femoroacetabular impingement: multicentre randomised controlled trial. BMJ 364:1185

11. Dwyer T, Whelan D, Shah PS, Ajrawat P, Hoit G, Chahal J (2020) Operative versus nonoperative treatment of femoroacetabular impingement syndrome: a meta-analysis of short-term outcomes. Arthroscopy 36:263-273

12. Salva JE, Merrill AE (2017) Signaling networks in joint development. Dev Dyn 246:262-274

13. Chijimatsu R, Saito T (2019) Mechanisms of synovial joint and articular cartilage development. Cell Mol Life Sci 76:3939-3952

14. Mitrovic DR (1977) Development of the metatarsophalangeal joint of the chick embryo: morphological, ultrastructural and histochemical studies. Am J Anat 150:333-347

15. Jenner F, A IJ, Cleary M, Heijsman D, Narcisi R, van der Spek PJ, Kremer A, van Weeren R, Brama P, van Osch GJ (2014) Differential gene expression of the intermediate and outer interzone layers of developing articular cartilage in murine embryos. Stem Cells Dev 23:1883-1898

16. Holder N (1977) An experimental investigation into the early development of the chick elbow joint. J Embryol Exp Morphol 39:115-127

17. Craig FM, Bentley G, Archer CW (1987) The spatial and temporal pattern of collagens I and II and keratan sulphate in the developing chick metatarsophalangeal joint. Development 99:383-391 
18. Hotten G, Neidhardt H, Jacobowsky B, Pohl J (1994) Cloning and expression of recombinant human growth/differentiation factor 5. Biochem Biophys Res Commun 204:646-652

19. Storm EE, Huynh TV, Copeland NG, Jenkins NA, Kingsley DM, Lee SJ (1994) Limb alterations in brachypodism mice due to mutations in a new member of the TGF beta-superfamily. Nature 368:639-643

20. Storm EE, Kingsley DM (1996) Joint patterning defects caused by single and double mutations in members of the bone morphogenetic protein (BMP) family. Development 122:3969-3979

21. Francis-West PH, Abdelfattah A, Chen P, Allen C, Parish J, Ladher R, Allen S, MacPherson S, Luyten FP, Archer CW (1999) Mechanisms of GDF-5 action during skeletal development. Development 126:1305-1315

22. Brunet LJ, McMahon JA, McMahon AP, Harland RM (1998) Noggin, cartilage morphogenesis, and joint formation in the mammalian skeleton. Science 280:1455-1457

23. Francis-West PH, Parish J, Lee K, Archer CW (1999) BMP/GDFsignalling interactions during synovial joint development. Cell Tissue Res 296:111-119

24. Spater D, Hill TP, Gruber M, Hartmann C (2006) Role of canonical Wnt-signalling in joint formation. Eur Cell Mater 12:71-80

25. Spater D, Hill TP, O'Sullivan RJ, Gruber M, Conner DA, Hartmann C (2006) Wnt9a signaling is required for joint integrity and regulation of Ihh during chondrogenesis. Development 133:3039-3049

26. Vortkamp A, Lee K, Lanske B, Segre GV, Kronenberg HM, Tabin CJ (1996) Regulation of rate of cartilage differentiation by Indian hedgehog and PTH-related protein. Science 273:613-622

27. Lanske B, Karaplis AC, Lee K, Luz A, Vortkamp A, Pirro A, Karperien M, Defize LH, Ho C, Mulligan RC, Abou-Samra AB, Juppner H, Segre GV, Kronenberg HM (1996) PTH/PTHrP receptor in early development and Indian hedgehog-regulated bone growth. Science 273:663-666

28. Ballard KJ, Holt SJ (1968) Cytological and cytochemical studies on cell death and digestion in the foetal rat foot: the role of macrophages and hydrolytic enzymes. J Cell Sci 3:245-262

29. Mankin HJ (1964) Mitosis in articular cartilage of immature rabbits. A histologic, stathmokinetic (colchicine) and autoradiographic study. Clin Orthop Relat Res 34:170-183

30. Ito MM, Kida MY (2000) Morphological and biochemical reevaluation of the process of cavitation in the rat knee joint: cellular and cell strata alterations in the interzone. J Anat 197(Pt 4):659-679

31. Lamb KJ, Lewthwaite JC, Lin JP, Simon D, Kavanagh E, Wheeler-Jones CP, Pitsillides AA (2003) Diverse range of fixed positional deformities and bone growth restraint provoked by flaccid paralysis in embryonic chicks. Int J Exp Pathol 84:191-199

32. Murray PD, Drachman DB (1969) The role of movement in the development of joints and related structures: the head and neck in the chick embryo. J Embryol Exp Morphol 22:349-371

33. Mitrovic D (1982) Development of the articular cavity in paralyzed chick embryos and in chick embryo limb buds cultured on chorioallantoic membranes. Acta Anat (Basel) 113:313-324

34. Osborne AC, Lamb KJ, Lewthwaite JC, Dowthwaite GP, Pitsillides AA (2002) Short-term rigid and flaccid paralyses diminish growth of embryonic chick limbs and abrogate joint cavity formation but differentially preserve pre-cavitated joints. J Musculoskelet Neuronal Interact 2:448-456

35. Dowthwaite GP, Edwards JC, Pitsillides AA (1998) An essential role for the interaction between hyaluronan and hyaluronan binding proteins during joint development. J Histochem Cytochem 46:641-651

36. Archer CW, Dowthwaite GP, Francis-West P (2003) Development of synovial joints. Birth Defects Res C 69:144-155
37. Giorgi M, Carriero A, Shefelbine SJ, Nowlan NC (2015) Effects of normal and abnormal loading conditions on morphogenesis of the prenatal hip joint: application to hip dysplasia. J Biomech 48:3390-3397

38. Ford CA, Nowlan NC, Thomopoulos S, Killian ML (2017) Effects of imbalanced muscle loading on hip joint development and maturation. J Orthop Res 35:1128-1136

39. Brunt LH, Skinner RE, Roddy KA, Araujo NM, Rayfield EJ, Hammond CL (2016) Differential effects of altered patterns of movement and strain on joint cell behaviour and skeletal morphogenesis. Osteoarthritis Cartilage 24:1940-1950

40. Seo HS, Serra R (2007) Deletion of Tgfbr2 in Prx1-cre expressing mesenchyme results in defects in development of the long bones and joints. Dev Biol 310:304-316

41. Jain L (2018) Hormonal regulation of human development. Clin Perinatol 45:xiii-xv

42. Decker RS (2017) Articular cartilage and joint development from embryogenesis to adulthood. Semin Cell Dev Biol 62:50-56

43. Harcke HT (1999) Developmental dysplasia of the hip: a spectrum of abnormality. Pediatrics 103:152

44. Loder RT, Skopelja EN (2011) The epidemiology and demographics of hip dysplasia. ISRN Orthop 2011:238607

45. Bjerkreim I, van der Hagen CB (1974) Congenital dislocation of the hip joint in Norway. V. Evaluation of genetic and environmental factors. Clin Genet 5:433-448

46. Li L, Sun K, Zhang L, Zhao Q, Cheng X, Dang Y (2013) Heritability and sibling recurrent risk of developmental dysplasia of the hip in Chinese population. Eur J Clin Investig 43:589-594

47. Atasu M, Akkoyunlu U, Tokgozoglu N, Say B (1972) The heritability of liability to congenital dislocation of the hip. Turk $\mathrm{J}$ Pediatr 14:23-26

48. Stevenson DA, Mineau G, Kerber RA, Viskochil DH, Schaefer C, Roach JW (2009) Familial predisposition to developmental dysplasia of the hip. J Pediatr Orthop 29:463-466

49. Hatzikotoulas K, Roposch A, Consortium DDHCC, Shah KM, Clark MJ, Bratherton S, Limbani V, Steinberg J, Zengini E, Warsame K, Ratnayake M, Tselepi M, Schwartzentruber J, Loughlin J, Eastwood DM, Zeggini E, Wilkinson JM (2018) Genome-wide association study of developmental dysplasia of the hip identifies an association with GDF5. Commun Biol 1:56

50. Yang J, Lee SH, Goddard ME, Visscher PM (2011) GCTA: a tool for genome-wide complex trait analysis. Am J Hum Genet 88:76-82

51. Feldman G, Dalsey C, Fertala K, Azimi D, Fortina P, Devoto M, Pacifici M, Parvizi J (2010) The Otto Aufranc Award: identification of a $4 \mathrm{Mb}$ region on chromosome 17q21 linked to developmental dysplasia of the hip in one 18-member, multigeneration family. Clin Orthop Relat Res 468:337-344

52. Mabuchi A, Nakamura S, Takatori Y, Ikegawa S (2006) Familial osteoarthritis of the hip joint associated with acetabular dysplasia maps to chromosome 13q. Am J Hum Genet 79:163-168

53. Watson CM, Crinnion LA, Gleghorn L, Newman WG, Ramesar $\mathrm{R}$, Beighton P, Wallis GA (2015) Identification of a mutation in the ubiquitin-fold modifier 1-specific peptidase 2 gene, UFSP2, in an extended South African family with Beukes hip dysplasia. S Afr Med J 105:558-563

54. Imabayashi H, Mori $\mathrm{T}$, Gojo S, Kiyono $\mathrm{T}$, Sugiyama $\mathrm{T}$, Irie R, Isogai T, Hata J, Toyama Y, Umezawa A (2003) Redifferentiation of dedifferentiated chondrocytes and chondrogenesis of human bone marrow stromal cells via chondrosphere formation with expression profiling by large-scale cDNA analysis. Exp Cell Res 288:35-50

55. Vetter K, Wurst W (2001) Expression of a novel mouse gene ' $m b F Z b$ ' in distinct regions of the developing nervous system and the adult brain. Mech Dev 100:123-125 
56. Deng FY, Dong SS, Xu XH, Liu YJ, Liu YZ, Shen H, Tian Q, Li J, Deng HW (2013) Genome-wide association study identified UQCC locus for spine bone size in humans. Bone 53:129-133

57. Sanna S, Jackson AU, Nagaraja R, Willer CJ, Chen WM, Bonnycastle LL, Shen H, Timpson N, Lettre G, Usala G, Chines PS, Stringham HM, Scott LJ, Dei M, Lai S, Albai G, Crisponi L, Naitza S, Doheny KF, Pugh EW, Ben-Shlomo Y, Ebrahim S, Lawlor DA, Bergman RN, Watanabe RM, Uda M, Tuomilehto J, Coresh J, Hirschhorn JN, Shuldiner AR, Schlessinger D, Collins FS, Davey Smith G, Boerwinkle E, Cao A, Boehnke M, Abecasis GR, Mohlke KL (2008) Common variants in the GDF5-UQCC region are associated with variation in human height. Nat Genet 40:198-203

58. Soranzo N, Rivadeneira F, Chinappen-Horsley U, Malkina I, Richards JB, Hammond N, Stolk L, Nica A, Inouye M, Hofman A, Stephens J, Wheeler E, Arp P, Gwilliam R, Jhamai PM, Potter S, Chaney A, Ghori MJ, Ravindrarajah R, Ermakov S, Estrada K, Pols HA, Williams FM, McArdle WL, van Meurs JB, Loos RJ, Dermitzakis ET, Ahmadi KR, Hart DJ, Ouwehand WH, Wareham NJ, Barroso I, Sandhu MS, Strachan DP, Livshits G, Spector TD, Uitterlinden AG, Deloukas P (2009) Meta-analysis of genome-wide scans for human adult stature identifies novel Loci and associations with measures of skeletal frame size. PLoS Genet 5:e1000445

59. Borkakoti N (1998) Matrix metalloproteases: variations on a theme. Prog Biophys Mol Biol 70:73-94

60. Fontenele EG, Moraes ME, d'Alva CB, Pinheiro DP, Landim SA, Barros FA, Trarbach EB, Mendonca BB, Jorge AA (2015) Association study of GWAS-derived loci with height in Brazilian children: importance of MAP3K3, MMP24 and IGF1R polymorphisms for height variation. Horm Res Paediatr 84:248-253

61. Zhao J, Li M, Bradfield JP, Zhang H, Mentch FD, Wang K, Sleiman PM, Kim CE, Glessner JT, Hou C, Keating BJ, Thomas KA, Garris ML, Deliard S, Frackelton EC, Otieno FG, Chiavacci RM, Berkowitz RI, Hakonarson H, Grant SF (2010) The role of height-associated loci identified in genome wide association studies in the determination of pediatric stature. BMC Med Genet 11:96

62. Moise AR, Kuksa V, Imanishi Y, Palczewski K (2004) Identification of all-trans-retinol: all-trans-13,14-dihydroretinol saturase. J Biol Chem 279:50230-50242

63. Ross SA, McCaffery PJ, Drager UC, De Luca LM (2000) Retinoids in embryonal development. Physiol Rev 80:1021-1054

64. Loder RT, Skopelja EN (2011) The epidemiology and demographics of legg-calve-perthes' disease. ISRN Orthop 2011:504393

65. Hall DJ (1986) Genetic aspects of Perthes' disease. A critical review. Clin Orthop Relat Res 209:100-114

66. Metcalfe D, Van Dijck S, Parsons N, Christensen K, Perry DC (2016) A twin study of perthes disease. Pediatrics 137:e20153542

67. Woratanarat $\mathrm{P}$, Thaveeratitharm $\mathrm{C}$, Woratanarat $\mathrm{T}$, Angsanuntsukh C, Attia J, Thakkinstian A (2014) Meta-analysis of hypercoagulability genetic polymorphisms in Perthes disease. J Orthop Res 32:1-7

68. Loder RT, Skopelja EN (2011) The epidemiology and demographics of slipped capital femoral epiphysis. ISRN Orthop 2011:486512

69. Rennie AM (1982) The inheritance of slipped upper femoral epiphysis. J Bone Jt Surg Br 64:180-184

70. Witbreuk M, van Kemenade FJ, van der Sluijs JA, Jansma EP, Rotteveel J, van Royen BJ (2013) Slipped capital femoral epiphysis and its association with endocrine, metabolic and chronic diseases: a systematic review of the literature. J Child Orthop 7:213-223

71. Ito K, Minka MA 2nd, Leunig M, Werlen S, Ganz R (2001) Femoroacetabular impingement and the cam-effect. A MRI-based quantitative anatomical study of the femoral head-neck offset. J Bone Jt Surg Br 83:171-176

72. Ganz R, Parvizi J, Beck M, Leunig M, Notzli H, Siebenrock KA (2003) Femoroacetabular impingement: a cause for osteoarthritis of the hip. Clin Orthop Relat Res 417:112-120

73. Beck M, Kalhor M, Leunig M, Ganz R (2005) Hip morphology influences the pattern of damage to the acetabular cartilage: femoroacetabular impingement as a cause of early osteoarthritis of the hip. J Bone Jt Surg Br 87:1012-1018

74. Agricola R, Bessems JH, Ginai AZ, Heijboer MP, van der Heijden RA, Verhaar JA, Weinans H, Waarsing JH (2012) The development of Cam-type deformity in adolescent and young male soccer players. Am J Sports Med 40:1099-1106

75. van Klij P, Heerey J, Waarsing JH, Agricola R (2018) The prevalence of cam and pincer morphology and its association with development of hip osteoarthritis. J Orthop Sports Phys Ther 48:230-238

76. Laborie LB, Lehmann TG, Engesaeter IO, Eastwood DM, Engesaeter LB, Rosendahl K (2011) Prevalence of radiographic findings thought to be associated with femoroacetabular impingement in a population-based cohort of 2081 healthy young adults. Radiology 260:494-502

77. Laborie LB, Lehmann TG, Engesaeter IO, Engesaeter LB, Rosendahl K (2013) Is a positive femoroacetabular impingement test a common finding in healthy young adults? Clin Orthop Relat Res 471:2267-2277

78. Laborie LB, Lehmann TG, Engesaeter IO, Sera F, Engesaeter LB, Rosendahl K (2014) The alpha angle in cam-type femoroacetabular impingement: new reference intervals based on 2038 healthy young adults. Bone Jt J 96-B:449-454

79. van Klij P, Heijboer MP, Ginai AZ, Verhaar JAN, Waarsing JH, Agricola R (2019) Cam morphology in young male football players mostly develops before proximal femoral growth plate closure: a prospective study with 5-yearfollow-up. Br J Sports Med 53:532-538

80. Pollard TC, Batra RN, Judge A, Watkins B, McNally EG, Gill HS, Thomas GE, Glyn-Jones S, Arden NK, Carr AJ (2013) The hereditary predisposition to hip osteoarthritis and its association with abnormal joint morphology. Osteoarthritis Cartilage 21:314-321

81. Heimann T, Meinzer HP (2009) Statistical shape models for 3D medical image segmentation: a review. Med Image Anal 13:543-563

82. Yokota F, Okada T, Takao M, Sugano N, Tada Y, Sato Y (2009) Automated segmentation of the femur and pelvis from 3D CT data of diseased hip using hierarchical statistical shape model of joint structure. Med Image Comput Comput Assist Interv $12: 811-818$

83. Lindner $\mathrm{C}$, Thiagarajah $\mathrm{S}$, Wilkinson JM, arc OC, Wallis GA, Cootes TF (2013) Development of a fully automatic shape model matching (FASMM) system to derive statistical shape models from radiographs: application to the accurate capture and global representation of proximal femur shape. Osteoarthritis Cartilage 21:1537-1544

84. Lindner C, Thiagarajah S, Wilkinson JM, Wallis GA, Cootes TF, arc OC (2013) Accurate bone segmentation in 2D radiographs using fully automatic shape model matching based on regression-voting. Med Image Comput Comput Assist Interv $16: 181-189$

85. Fitzpatrick CK, Baldwin MA, Laz PJ, FitzPatrick DP, Lerner AL, Rullkoetter PJ (2011) Development of a statistical shape model of the patellofemoral joint for investigating relationships between shape and function. J Biomech 44:2446-2452

86. Van Haver A, Mahieu P, Claessens T, Li H, Pattyn C, Verdonk P, Audenaert EA (2014) A statistical shape model of trochlear dysplasia of the knee. Knee 21:518-523 
87. Pedoia V, Lansdown DA, Zaid M, McCulloch CE, Souza R, Ma CB, Li X (2015) Three-dimensional MRI-based statistical shape model and application to a cohort of knees with acute ACL injury. Osteoarthritis Cartilage 23:1695-1703

88. Khanduja V, Baelde N, Dobbelaere A, Van Houcke J, Li H, Pattyn C, Audenaert EA (2016) Patient-specific assessment of dysmorphism of the femoral head-neck junction: a statistical shape model approach. Int J Med Robot 12:765-772

89. Baird DA, Evans DS, Kamanu FK, Gregory JS, Saunders FR, Giuraniuc CV, Barr RJ, Aspden RM, Jenkins D, Kiel DP, Orwoll ES, Cummings SR, Lane NE, Mullin BH, Williams FM, Richards JB, Wilson SG, Spector TD, Faber BG, Lawlor DA, Grundberg E, Ohlsson C, Pettersson-Kymmer U, Capellini TD, Richard D, Beck TJ, Evans DM, Paternoster L, Karasik D, Tobias JH (2019) Identification of novel loci associated with hip shape: a meta-analysis of genomewide association studies. J Bone Miner Res 34:241-251

90. Hsu YH, Estrada K, Evangelou E, Ackert-Bicknell C, Akesson K, Beck T, Brown SJ, Capellini T, Carbone L, Cauley J, Cheung CL, Cummings SR, Czerwinski S, Demissie S, Econs M, Evans D, Farber C, Gautvik K, Harris T, Kammerer C, Kemp J, Koller DL, Kung A, Lawlor D, Lee M, Lorentzon M, McGuigan F, Medina-Gomez C, Mitchell B, Newman A, Nielson C, Ohlsson C, Peacock M, Reppe S, Richards JB, Robbins J, Sigurdsson G, Spector TD, Stefansson K, Streeten E, Styrkarsdottir U, Tobias J, Trajanoska K, Uitterlinden A, Vandenput L, Wilson SG, Yerges-Armstrong L, Young M, Zillikens MC, Rivadeneira F, Kiel DP, Karasik D (2019) Meta-analysis of genomewide association studies reveals genetic variants for hip bone geometry. J Bone Miner Res 34:1284-1296

91. Zheng J, Erzurumluoglu AM, Elsworth BL, Kemp JP, Howe L, Haycock PC, Hemani G, Tansey K, Laurin C, Early G, Lifecourse Epidemiology Eczema C, Pourcain BS, Warrington NM, Finucane HK, Price AL, Bulik-Sullivan BK, Anttila V, Paternoster L, Gaunt TR, Evans DM, Neale BM (2017) LD Hub: a centralized database and web interface to perform LD score regression that maximizes the potential of summary level GWAS data for SNP heritability and genetic correlation analysis. Bioinformatics 33:272-279

92. Styrkarsdottir U, Stefansson OA, Gunnarsdottir K, Thorleifsson G, Lund SH, Stefansdottir L, Juliusson K, Agustsdottir AB, Zink F, Halldorsson GH, Ivarsdottir EV, Benonisdottir S, Jonsson H, Gylfason A, Norland K, Trajanoska K, Boer CG, Southam L, Leung JCS, Tang NLS, Kwok TCY, Lee JSW, Ho SC, Byrjalsen I, Center JR, Lee SH, Koh JM, Lohmander LS, Ho-Pham LT, Nguyen TV, Eisman JA, Woo J, Leung PC, Loughlin J, Zeggini E, Christiansen C, Rivadeneira F, van Meurs J, Uitterlinden AG, Mogensen B, Jonsson H, Ingvarsson T, Sigurdsson G, Benediktsson R, Sulem P, Jonsdottir I, Masson G, Holm H, Norddahl GL, Thorsteinsdottir U, Gudbjartsson DF, Stefansson K (2019) GWAS of bone size yields twelve loci that also affect height, BMD, osteoarthritis or fractures. Nat Commun 10:2054

93. Lehmann TG, Engesaeter IO, Laborie LB, Lie SA, Rosendahl K, Engesaeter LB (2012) Total hip arthroplasty in young adults, with focus on Perthes' disease and slipped capital femoral epiphysis: follow-up of 540 subjects reported to the Norwegian Arthroplasty Register during 1987-2007. Acta Orthop 83:159-164

94. Wiberg G (1939) Studies on dysplastic acetabula and congenital subluxation of the hip joint with special references to the complication of osteoarthritis. Acta Chir Scand 83:1-135

95. Cooperman DR, Wallensten R, Stulberg SD (1983) Acetabular dysplasia in the adult. Clin Orthop Relat Res 175:79-85

96. McWilliams DF, Doherty SA, Jenkins WD, Maciewicz RA, Muir KR, Zhang W, Doherty M (2010) Mild acetabular dysplasia and risk of osteoarthritis of the hip: a case-control study. Ann Rheum Dis 69:1774-1778

97. Murray RO (1965) The aetiology of primary osteoarthritis of the hip. Br J Radiol 38:810-824

98. Solomon L (1976) Patterns of osteoarthritis of the hip. J Bone Jt Surg Br 58:176-183

99. Harris WH (1986) Etiology of osteoarthritis of the hip. Clin Orthop Relat Res 213:20-33

100. Ganz R, Leunig M, Leunig-Ganz K, Harris WH (2008) The etiology of osteoarthritis of the hip: an integrated mechanical concept. Clin Orthop Relat Res 466:264-272

101. Doherty M, Courtney P, Doherty S, Jenkins W, Maciewicz RA, Muir K, Zhang W (2008) Nonspherical femoral head shape (pistol grip deformity), neck shaft angle, and risk of hip osteoarthritis: a case-control study. Arthritis Rheum 58:3172-3182

102. Kim YH (1989) Relationship between the sphericity of femoral head-acetabulum and the low incidence of primary osteoarthritis of the hip joint in Koreans. Yonsei Med J 30:280-287

103. Dudda M, Kim YJ, Zhang Y, Nevitt MC, Xu L, Niu J, Goggins J, Doherty M, Felson DT (2011) Morphologic differences between the hips of Chinese women and white women: could they account for the ethnic difference in the prevalence of hip osteoarthritis? Arthritis Rheum 63:2992-2999

104. Edwards K, Leyland KM, Sanchez-Santos MT, Arden CP, Spector TD, Nelson AE, Jordan JM, Nevitt M, Hunter DJ, Arden NK (2019) Differences between race and sex in measures of hip morphology: a population-based comparative study. Osteoarthritis Cartilage. https://doi.org/10.1016/j.joca.2019.10.014

105. Hoaglund FT (2013) Primary osteoarthritis of the hip: a genetic disease caused by European genetic variants. J Bone Jt Surg Am 95:463-468

106. Nicholls AS, Kiran A, Pollard TC, Hart DJ, Arden CP, Spector T, Gill HS, Murray DW, Carr AJ, Arden NK (2011) The association between hip morphology parameters and nineteen-year risk of end-stage osteoarthritis of the hip: a nested case-control study. Arthritis Rheum 63:3392-3400

107. Thomas GE, Palmer AJ, Batra RN, Kiran A, Hart D, Spector T, Javaid MK, Judge A, Murray DW, Carr AJ, Arden NK, GlynJones S (2014) Subclinical deformities of the hip are significant predictors of radiographic osteoarthritis and joint replacement in women. A 20 year longitudinal cohort study. Osteoarthritis Cartilage 22:1504-1510

108. Agricola R, Heijboer MP, Bierma-Zeinstra SM, Verhaar JA, Weinans H, Waarsing JH (2013) Cam impingement causes osteoarthritis of the hip: a nationwide prospective cohort study (CHECK). Ann Rheum Dis 72:918-923

109. Agricola R, Heijboer MP, Roze RH, Reijman M, Bierma-Zeinstra SM, Verhaar JA, Weinans H, Waarsing JH (2013) Pincer deformity does not lead to osteoarthritis of the hip whereas acetabular dysplasia does: acetabular coverage and development of osteoarthritis in a nationwide prospective cohort study (CHECK). Osteoarthritis Cartilage 21:1514-1521

110. Waarsing JH, Rozendaal RM, Verhaar JA, Bierma-Zeinstra SM, Weinans H (2010) A statistical model of shape and density of the proximal femur in relation to radiological and clinical OA of the hip. Osteoarthritis Cartilage 18:787-794

111. Castano-Betancourt MC, Van Meurs JB, Bierma-Zeinstra S, Rivadeneira F, Hofman A, Weinans H, Uitterlinden AG, Waarsing JH (2013) The contribution of hip geometry to the prediction of hip osteoarthritis. Osteoarthritis Cartilage 21:1530-1536

112. Agricola R, Leyland KM, Bierma-Zeinstra SM, Thomas GE, Emans PJ, Spector TD, Weinans H, Waarsing JH, Arden NK (2015) Validation of statistical shape modelling to predict hip osteoarthritis in females: data from two prospective cohort studies (Cohort Hip and Cohort Knee and Chingford). Rheumatology (Oxford) 54:2033-2041 
113. Baker-Lepain JC, Lynch JA, Parimi N, McCulloch CE, Nevitt MC, Corr M, Lane NE (2012) Variant alleles of the Wnt antagonist FRZB are determinants of hip shape and modify the relationship between hip shape and osteoarthritis. Arthritis Rheum 64:1457-1465

114. Panoutsopoulou K, Southam L, Elliott KS, Wrayner N, Zhai G, Beazley C, Thorleifsson G, Arden NK, Carr A, Chapman K, Deloukas P, Doherty M, McCaskie A, Ollier WE, Ralston SH, Spector TD, Valdes AM, Wallis GA, Wilkinson JM, Arden E, Battley K, Blackburn H, Blanco FJ, Bumpstead S, Cupples LA, Day-Williams AG, Dixon K, Doherty SA, Esko T, Evangelou E, Felson D, Gomez-Reino JJ, Gonzalez A, Gordon A, Gwilliam R, Halldorsson BV, Hauksson VB, Hofman A, Hunt SE, Ioannidis JP, Ingvarsson T, Jonsdottir I, Jonsson H, Keen R, Kerkhof HJ, Kloppenburg MG, Koller N, Lakenberg N, Lane NE, Lee AT, Metspalu A, Meulenbelt I, Nevitt MC, O'Neill F, Parimi N, Potter SC, Rego-Perez I, Riancho JA, Sherburn K, Slagboom PE, Stefansson K, Styrkarsdottir U, Sumillera M, Swift D, Thorsteinsdottir U, Tsezou A, Uitterlinden AG, van Meurs JB, Watkins B, Wheeler M, Mitchell S, Zhu Y, Zmuda JM, Zeggini E, Loughlin J (2011) Insights into the genetic architecture of osteoarthritis from stage 1 of the arcOGEN study. Ann Rheum Dis 70:864-867

115. Lindner C, Thiagarajah S, Wilkinson JM, Panoutsopoulou K, Day-Williams AG, arc OC, Cootes TF, Wallis GA (2015) Investigation of association between hip osteoarthritis susceptibility loci and radiographic proximal femur shape. Arthritis Rheumatol 67:2076-2084

116. Haverkamp DJ, Schiphof D, Bierma-Zeinstra SM, Weinans H, Waarsing JH (2011) Variation in joint shape of osteoarthritic knees. Arthritis Rheum 63:3401-3407

117. Wise BL, Niu J, Zhang Y, Liu F, Pang J, Lynch JA, Lane NE (2018) Bone shape mediates the relationship between sex and incident knee osteoarthritis. BMC Musculoskelet Disord 19:331

118. Gregory JS, Waarsing JH, Day J, Pols HA, Reijman M, Weinans H, Aspden RM (2007) Early identification of radiographic osteoarthritis of the hip using an active shape model to quantify changes in bone morphometric features: can hip shape tell us anything about the progression of osteoarthritis? Arthritis Rheum 56:3634-3643

119. Hunter D, Nevitt M, Lynch J, Kraus VB, Katz JN, Collins JE, Bowes M, Guermazi A, Roemer FW, Losina E, Consortium FOB (2016) Longitudinal validation of periarticular bone area and 3D shape as biomarkers for knee OA progression? Data from the FNIH OA Biomarkers Consortium. Ann Rheum Dis 75:1607-1614

120. Blake GM, Wahner HW, Fogelman I (1999) Technical principals of X-ray absorptiometry. In: Blake GM, Wahner HW, Fogelman I (eds) The evaluation of osteoporosis: dual energy X-ray absorptiometry and ultrasound in clinical practice. Martin Dunitz Ltd, London, pp 45-71

121. Inamdar G, Pedoia V, Rossi-Devries J, Samaan MA, Link TM, Souza RB, Majumdar S (2019) MR study of longitudinal variations in proximal femur 3D morphological shape and associations with cartilage health in hip osteoarthritis. J Orthop Res 37:161-170

122. Bombelli R (1983) Osteoarthritis of the hip: classification and pathogenesis. Springer-Verlag, Berlin

123. Panoutsopoulou K, Thiagarajah S, Zengini E, Day-Williams AG, Ramos YF, Meessen JM, Huetink K, Nelissen RG, Southam L, Rayner NW, arc OC, Doherty M, Meulenbelt I, Zeggini E, Wilkinson JM (2016) Radiographic endophenotyping in hip osteoarthritis improves the precision of genetic association analysis. Ann Rheum Dis. https://doi.org/10.1136/annrheumdi s-2016-210373
124. Zengini E, Hatzikotoulas K, Tachmazidou I, Steinberg J, Hartwig FP, Southam L, Hackinger S, Boer CG, Styrkarsdottir U, Gilly A, Suveges D, Killian B, Ingvarsson T, Jonsson H, Babis GC, McCaskie A, Uitterlinden AG, van Meurs JBJ, Thorsteinsdottir U, Stefansson K, Davey Smith G, Wilkinson JM, Zeggini E (2018) Genome-wide analyses using UK Biobank data provide insights into the genetic architecture of osteoarthritis. Nat Genet. https://doi.org/10.1038/s41588-018-0079-y

125. Tachmazidou I, Hatzikotoulas K, Southam L, Esparza-Gordillo J, Haberland V, Zheng J, Johnson T, Koprulu M, Zengini E, Steinberg J, Wilkinson JM, Bhatnagar S, Hoffman JD, Buchan N, Süveges D, Yerges-Armstrong L, Smith GD, Gaunt TR, Scott RA, McCarthy LC, Zeggini E, arc OC (2019) Identification of new therapeutic targets for osteoarthritis through genome-wide analyses of UK Biobank data. Nat Genet. https://doi.org/10.1038/ s41588-018-0327-1

126. Styrkarsdottir U, Helgason H, Sigurdsson A, Norddahl GL, Agustsdottir AB, Reynard LN, Villalvilla A, Halldorsson GH, Jonasdottir A, Magnusdottir A, Oddson A, Sulem G, Zink F, Sveinbjornsson G, Helgason A, Johannsdottir HS, Helgadottir A, Stefansson H, Gretarsdottir S, Rafnar T, Almdahl IS, Braekhus A, Fladby T, Selbaek G, Hosseinpanah F, Azizi F, Koh JM, Tang NLS, Daneshpour MS, Mayordomo JI, Welt C, Braund PS, Samani NJ, Kiemeney LA, Lohmander LS, Christiansen C, Andreassen OA, arc Oc, Magnusson O, Masson G, Kong A, Jonsdottir I, Gudbjartsson D, Sulem P, Jonsson H, Loughlin J, Ingvarsson T, Thorsteinsdottir U, Stefansson K (2017) Whole-genome sequencing identifies rare genotypes in COMP and CHADL associated with high risk of hip osteoarthritis. Nat Genet 49:801-805

127. Styrkarsdottir U, Lund SH, Thorleifsson G, Zink F, Stefansson OA, Sigurdsson JK, Juliusson K, Bjarnadottir K, Sigurbjornsdottir S, Jonsson S, Norland K, Stefansdottir L, Sigurdsson A, Sveinbjornsson G, Oddsson A, Bjornsdottir G, Gudmundsson RL, Halldorsson GH, Rafnar T, Jonsdottir I, Steingrimsson E, Norddahl GL, Masson G, Sulem P, Jonsson H, Ingvarsson T, Gudbjartsson DF, Thorsteinsdottir U, Stefansson K (2018) Metaanalysis of Icelandic and UK data sets identifies missense variants in SMO, IL11, COL11A1 and 13 more new loci associated with osteoarthritis. Nat Genet 50:1681-1687

128. arcOGEN Consortium; arcOGEN Collaborators ZE, Panoutsopoulou K, Southam L, Rayner NW, Day-Williams AG, Lopes MC, Boraska V, Esko T, Evangelou E, Hoffman A, HouwingDuistermaat JJ, Ingvarsson T, Jonsdottir I, Jonnson H, Kerkhof HJ, Kloppenburg M, Bos SD, Mangino M, Metrustry S, Slagboom PE, Thorleifsson G, Raine EV, Ratnayake M, Ricketts M, Beazley C, Blackburn H, Bumpstead S, Elliott KS, Hunt SE, Potter SC, Shin SY, Yadav VK, Zhai G, Sherburn K, Dixon K, Arden E, Aslam N, Battley PK, Carluke I, Doherty S, Gordon A, Joseph J, Keen R, Koller NC, Mitchell S, O’Neill F, Paling E, Reed MR, Rivadeneira F, Swift D, Walker K, Watkins B, Wheeler M, Birrell F, Ioannidis JP, Meulenbelt I, Metspalu A, Rai A, Salter D, Stefansson K, Stykarsdottir U, Uitterlinden AG, van Meurs JB, Chapman K, Deloukas P, Ollier WE, Wallis GA, Arden N, Carr A, Doherty M, McCaskie A, Willkinson JM, Ralston SH, Valdes AM, Spector TD, Loughlin J (2012) Identification of new susceptibility loci for osteoarthritis (arcOGEN): a genome-wide association study. Lancet 380:815-823

129. Reynard LN, Barter MJ (2019) Osteoarthritis year in review 2019: genetics, genomics and epigenetics. Osteoarthritis Cartilage. https://doi.org/10.1016/j.joca.2019.11.010

130. Miyamoto Y, Mabuchi A, Shi D, Kubo T, Takatori Y, Saito S, Fujioka M, Sudo A, Uchida A, Yamamoto S, Ozaki K, Takigawa M, Tanaka T, Nakamura Y, Jiang Q, Ikegawa S (2007) A functional polymorphism in the 5' UTR of GDF5 is associated with susceptibility to osteoarthritis. Nat Genet 39:529-533 
131. Miyamoto Y, Shi D, Nakajima M, Ozaki K, Sudo A, Kotani A, Uchida A, Tanaka T, Fukui N, Tsunoda T, Takahashi A, Nakamura Y, Jiang Q, Ikegawa S (2008) Common variants in DVWA on chromosome 3 p24.3 are associated with susceptibility to knee osteoarthritis. Nat Genet 40:994-998

132. Nakajima M, Takahashi A, Kou I, Rodriguez-Fontenla C, Gomez-Reino JJ, Furuichi T, Dai J, Sudo A, Uchida A, Fukui N, Kubo M, Kamatani N, Tsunoda T, Malizos KN, Tsezou A, Gonzalez A, Nakamura Y, Ikegawa S (2010) New sequence variants in HLA class II/III region associated with susceptibility to knee osteoarthritis identified by genome-wide association study. PLoS ONE 5:e9723

133. Kerkhof HJ, Lories RJ, Meulenbelt I, Jonsdottir I, Valdes AM, Arp P, Ingvarsson T, Jhamai M, Jonsson H, Stolk L, Thorleifsson G, Zhai G, Zhang F, Zhu Y, van der Breggen R, Carr A, Doherty M, Doherty S, Felson DT, Gonzalez A, Halldorsson BV, Hart DJ, Hauksson VB, Hofman A, Ioannidis JP, Kloppenburg M, Lane NE, Loughlin J, Luyten FP, Nevitt MC, Parimi N, Pols HA, Rivadeneira F, Slagboom EP, Styrkarsdottir U, Tsezou A, van de Putte T, Zmuda J, Spector TD, Stefansson K, Uitterlinden AG, van Meurs JB (2010) A genome-wide association study identifies an osteoarthritis susceptibility locus on chromosome $7 \mathrm{q} 22$. Arthritis Rheum 62:499-510

134. Evangelou E, Valdes AM, Kerkhof HJ, Styrkarsdottir U, Zhu Y, Meulenbelt I, Lories RJ, Karassa FB, Tylzanowski P, Bos SD, Akune T, Arden NK, Carr A, Chapman K, Cupples LA, Dai J, Deloukas P, Doherty M, Doherty S, Engstrom G, Gonzalez A, Halldorsson BV, Hammond CL, Hart DJ, Helgadottir H, Hofman A, Ikegawa S, Ingvarsson T, Jiang Q, Jonsson H, Kaprio J, Kawaguchi H, Kisand K, Kloppenburg M, Kujala UM, Lohmander LS, Loughlin J, Luyten FP, Mabuchi A, McCaskie A, Nakajima M, Nilsson PM, Nishida N, Ollier WE, Panoutsopoulou K, van de Putte T, Ralston SH, Rivadeneira F, Saarela J, Schulte-Merker S, Shi D, Slagboom PE, Sudo A, Tamm A, Thorleifsson G, Thorsteinsdottir U, Tsezou A, Wallis GA, Wilkinson JM, Yoshimura N, Zeggini E, Zhai G, Zhang F, Jonsdottir I, Uitterlinden AG, Felson DT, van Meurs JB, Stefansson K, Ioannidis JP, Spector TD (2011) Meta-analysis of genome-wide association studies confirms a susceptibility locus for knee osteoarthritis on chromosome 7q22. Ann Rheum Dis 70:349-355

135. Day-Williams AG, Southam L, Panoutsopoulou K, Rayner NW, Esko T, Estrada K, Helgadottir HT, Hofman A, Ingvarsson T, Jonsson H, Keis A, Kerkhof HJ, Thorleifsson G, Arden NK, Carr A, Chapman K, Deloukas P, Loughlin J, McCaskie A, Ollier WE, Ralston SH, Spector TD, Wallis GA, Wilkinson JM, Aslam N, Birell F, Carluke I, Joseph J, Rai A, Reed M, Walker K, Doherty SA, Jonsdottir I, Maciewicz RA, Muir KR, Metspalu A, Rivadeneira F, Stefansson K, Styrkarsdottir U, Uitterlinden AG, van Meurs JB, Zhang W, Valdes AM, Doherty M, Zeggini E (2011) A variant in MCF2L is associated with osteoarthritis. Am J Hum Genet. https://doi.org/10.1016/j.ajhg.2011.08.001

136. Evangelou E, Valdes AM, Castano-Betancourt MC, Doherty M, Doherty S, Esko T, Ingvarsson T, Ioannidis JP, Kloppenburg M, Metspalu A, Ntzani EE, Panoutsopoulou K, Slagboom PE, Southam L, Spector TD, Styrkarsdottir U, Stefanson K, Uitterlinden AG, Wheeler M, Zeggini E, Meulenbelt I, van Meurs JB, arcOgen consortium tT-OAc (2013) The DOT1L rs12982744 polymorphism is associated with osteoarthritis of the hip with genome-wide statistical significance in males. Ann Rheum Dis 72:1264-1265

137. Styrkarsdottir U, Thorleifsson G, Helgadottir HT, Bomer N, Metrustry S, Bierma-Zeinstra S, Strijbosch AM, Evangelou E, Hart D, Beekman M, Jonasdottir A, Sigurdsson A, Eiriksson FF, Thorsteinsdottir M, Frigge ML, Kong A, Gudjonsson SA, Magnusson OT, Masson G, Consortium T-O, arc OC, Hofman A, Arden NK, Ingvarsson T, Lohmander S, Kloppenburg M,
Rivadeneira F, Nelissen RG, Spector T, Uitterlinden A, Slagboom PE, Thorsteinsdottir U, Jonsdottir I, Valdes AM, Meulenbelt I, van Meurs J, Jonsson H, Stefansson K (2014) Severe osteoarthritis of the hand associates with common variants within the ALDH1A2 gene and with rare variants at $1 \mathrm{p} 31$. Nat Genet 46:498-502

138. Evangelou E, Kerkhof HJ, Styrkarsdottir U, Ntzani EE, Bos SD, Esko T, Evans DS, Metrustry S, Panoutsopoulou K, Ramos YF, Thorleifsson G, Tsilidis KK, arc OC, Arden N, Aslam N, Bellamy N, Birrell F, Blanco FJ, Carr A, Chapman K, Day-Williams AG, Deloukas P, Doherty M, Engstrom G, Helgadottir HT, Hofman A, Ingvarsson T, Jonsson H, Keis A, Keurentjes JC, Kloppenburg M, Lind PA, McCaskie A, Martin NG, Milani L, Montgomery GW, Nelissen RG, Nevitt MC, Nilsson PM, Ollier WE, Parimi N, Rai A, Ralston SH, Reed MR, Riancho JA, Rivadeneira F, Rodriguez-Fontenla C, Southam L, Thorsteinsdottir U, Tsezou A, Wallis GA, Wilkinson JM, Gonzalez A, Lane NE, Lohmander LS, Loughlin J, Metspalu A, Uitterlinden AG, Jonsdottir I, Stefansson K, Slagboom PE, Zeggini E, Meulenbelt I, Ioannidis JP, Spector TD, van Meurs JB, Valdes AM (2014) A meta-analysis of genomewide association studies identifies novel variants associated with osteoarthritis of the hip. Ann Rheum Dis 73:2130-2136

139. Hackinger S, Trajanoska K, Styrkarsdottir U, Zengini E, Steinberg J, Ritchie GRS, Hatzikotoulas K, Gilly A, Evangelou E, Kemp JP, arcOgen Consortium GC, Evans D, Ingvarsson T, Jonsson H, Thorsteinsdottir U, Stefansson K, McCaskie AW, Brooks RA, Wilkinson JM, Rivadeneira F, Zeggini E (2017) Evaluation of shared genetic aetiology between osteoarthritis and bone mineral density identifies SMAD3 as a novel osteoarthritis risk locus. Hum Mol Genet 26:3850-3858

140. Liu Y, Yau MS, Yerges-Armstrong LM, Duggan DJ, Renner JB, Hochberg MC, Mitchell BD, Jackson RD, Jordan JM (2017) Genetic determinants of radiographic knee osteoarthritis in African Americans. J Rheumatol 44:1652-1658

141. den Hollander W, Boer CG, Hart DJ, Yau MS, Ramos YFM, Metrustry S, Broer L, Deelen J, Cupples LA, Rivadeneira F, Kloppenburg M, Peters M, Spector TD, Hofman A, Slagboom PE, Nelissen R, Uitterlinden AG, Felson DT, Valdes AM, Meulenbelt I, van Meurs JJB (2017) Genome-wide association and functional studies identify a role for matrix Gla protein in osteoarthritis of the hand. Ann Rheum Dis 76:2046-2053

142. Casalone E, Tachmazidou I, Zengini E, Hatzikotoulas K, Hackinger S, Suveges D, Steinberg J, Rayner NW, arc OC, Wilkinson JM, Panoutsopoulou K, Zeggini E (2018) A novel variant in GLIS3 is associated with osteoarthritis. Ann Rheum Dis 77:620-623

143. Baird DA, Paternoster L, Gregory JS, Faber BG, Saunders FR, Giuraniuc CV, Barr RJ, Lawlor DA, Aspden RM, Tobias JH (2018) Investigation of the relationship between susceptibility loci for hip osteoarthritis and dual X-ray absorptiometryderived hip shape in a population-based cohort of perimenopausal women. Arthritis Rheumatol 70:1984-1993

144. Everman DB, Bartels CF, Yang Y, Yanamandra N, Goodman FR, Mendoza-Londono JR, Savarirayan R, White SM, Graham JM Jr, Gale RP, Svarch E, Newman WG, Kleckers AR, Francomano CA, Govindaiah V, Singh L, Morrison S, Thomas JT, Warman ML (2002) The mutational spectrum of brachydactyly type C. Am J Med Genet 112:291-296

145. Valdes AM, Evangelou E, Kerkhof HJ, Tamm A, Doherty SA, Kisand K, Tamm A, Kerna I, Uitterlinden A, Hofman A, Rivadeneira F, Cooper C, Dennison EM, Zhang W, Muir KR, Ioannidis JP, Wheeler M, Maciewicz RA, van Meurs JB, Arden NK, Spector TD, Doherty M (2011) The GDF5 rs 143383 polymorphism is associated with osteoarthritis of the knee 
with genome-wide statistical significance. Ann Rheum Dis 70:873-875

146. Chen H, Capellini TD, Schoor M, Mortlock DP, Reddi AH, Kingsley DM (2016) Heads, shoulders, elbows, knees, and toes: modular Gdf5 enhancers control different joints in the vertebrate skeleton. PLoS Genet 12:e1006454

147. Capellini TD, Chen H, Cao J, Doxey AC, Kiapour AM, Schoor M, Kingsley DM (2017) Ancient selection for derived alleles at a GDF5 enhancer influencing human growth and osteoarthritis risk. Nat Genet. https://doi.org/10.1038/ng.3911

148. Richard D, Liu Z, Cao J, Kiapour AM, Willen J, Yarlagadda S, Jagoda E, Kolachalama VB, Sieker JT, Chang GH, Muthuirulan P, Young M, Masson A, Konrad J, Hosseinzadeh S, Maridas DE, Rosen V, Krawetz R, Roach N, Capellini TD (2020) Evolutionary selection and constraint on human knee chondrocyte regulation impacts osteoarthritis risk. Cell. https ://doi.org/10.1016/j.cell.2020.02.057

149. Corbani S, Chouery E, Eid B, Jalkh N, Ghoch JA, Megarbane A (2011) Mild campomelic dysplasia: report on a case and review. Mol Syndromol 1:163-168

150. Lefebvre V, Dvir-Ginzberg M (2017) SOX9 and the many facets of its regulation in the chondrocyte lineage. Connect Tissue Res 58:2-14

151. Komori $\mathrm{T}$ (2019) Regulation of proliferation, differentiation and functions of osteoblasts by Runx2. Int J Mol Sci 20:1694

152. Klopocki E, Hennig BP, Dathe K, Koll R, de Ravel T, Baten E, Blom E, Gillerot Y, Weigel JF, Kruger G, Hiort O, Seemann P, Mundlos S (2010) Deletion and point mutations of PTHLH cause brachydactyly type E. Am J Hum Genet 86:434-439

153. Feldman GJ, Parvizi J, Levenstien M, Scott K, Erickson JA, Fortina P, Devoto M, Peters CL (2013) Developmental dysplasia of the hip: linkage mapping and whole exome sequencing identify a shared variant in CX3CR1 in all affected members of a large multigeneration family. J Bone Miner Res 28:2540-2549

154. Basit S, Albalawi AM, Alharby E, Khoshhal KI (2017) Exome sequencing identified rare variants in genes HSPG2 and ATP2B4 in a family segregating developmental dysplasia of the hip. BMC Med Genet 18:34

155. Dai J, Shi D, Zhu P, Qin J, Ni H, Xu Y, Yao C, Zhu L, Zhu H, Zhao B, Wei J, Liu B, Ikegawa S, Jiang Q, Ding Y (2008) Association of a single nucleotide polymorphism in growth differentiate factor 5 with congenital dysplasia of the hip: a case-control study. Arthritis Res Ther 10:R126

156. Wang K, Shi D, Zhu P, Dai J, Zhu L, Zhu H, Lv Y, Zhao B, Jiang $\mathrm{Q}$ (2010) Association of a single nucleotide polymorphism in Tbx4 with developmental dysplasia of the hip: a case-control study. Osteoarthritis Cartilage 18:1592-1595
157. Shi D, Dai J, Zhu P, Qin J, Zhu L, Zhu H, Zhao B, Qiu X, Xu Z, Chen D, Yi L, Ikegawa S, Jiang Q (2011) Association of the D repeat polymorphism in the ASPN gene with developmental dysplasia of the hip: a case-control study in Han Chinese. Arthritis Res Ther 13:R27

158. Cengic T, Trkulja V, Pavelic SK, Ratkaj I, Markova-Car E, Mikolaucic M, Kolundzic R (2015) Association of TGFB1 29C/T and IL6 -572G/C polymorphisms with developmental hip dysplasia: a case-control study in adults with severe osteoarthritis. Int Orthop 39:793-798

159. Jia J, Li L, Zhao Q, Zhang L, Ru J, Liu X, Li Q, Shi L (2012) Association of a single nucleotide polymorphism in pregnancyassociated plasma protein-A2 with developmental dysplasia of the hip: a case-control study. Osteoarthritis Cartilage 20:60-63

160. Hao Z, Dai J, Shi D, Xu Z, Chen D, Zhao B, Teng H, Jiang $\mathrm{Q}$ (2014) Association of a single nucleotide polymorphism in HOXB9 with developmental dysplasia of the hip: a case-control study. J Orthop Res 32:179-182

161. Tian W, Zhao L, Wang J, Suo P, Wang J, Cheng L, Cheng Z, Jia J, Kan S, Wang B, Ma X (2012) Association analysis between HOXD9 genes and the development of developmental dysplasia of the hip in Chinese female Han population. BMC Musculoskelet Disord 13:59

162. Liu S, Tian W, Wang J, Cheng L, Jia J, Ma X (2014) Two singlenucleotide polymorphisms in the DKK1 gene are associated with developmental dysplasia of the hip in the Chinese Han female population. Genet Test Mol Biomark 18:557-561

163. Zhao L, Tian W, Pan H, Zhu X, Wang J, Cheng Z, Cheng L, Ma X, Wang B (2013) Variations of the COL1A1 gene promoter and the relation to developmental dysplasia of the hip. Genet Test Mol Biomark 17:840-843

164. Sun Y, Wang C, Hao Z, Dai J, Chen D, Xu Z, Shi D, Mao P, Teng H, Gao X, Hu Z, Shen H, Jiang Q (2015) A common variant of ubiquinol-cytochrome c reductase complex is associated with DDH. PLoS ONE 10:e0120212

165. Salazar VS, Gamer LW, Rosen V (2016) BMP signalling in skeletal development, disease and repair. Nat Rev Endocrinol 12:203-221

Publisher's Note Springer Nature remains neutral with regard to jurisdictional claims in published maps and institutional affiliations. 